\title{
PRECIPITATION AND THE NORTH ATLANTIC OSCILLATION: A STUDY OF CLIMATIC VARIABILITY IN NORTHERN ENGLAND
}

\author{
H. J. FOWLER* and C. G. KILSBY \\ Water Resource Systems Research Laboratory, Department of Civil Engineering, University of Newcastle upon Tyne, UK
}

\author{
Received 14 March 2001 \\ Revised 30 November 2001 \\ Accepted 2 December 2001
}

\begin{abstract}
Variations in precipitation in Yorkshire, UK, are linked to large-scale atmospheric circulation using the North Atlantic Oscillation (NAO) index, objective Lamb weather types, and long-term seasonal and annual precipitation indices at seven sites. Since the 1960s, a significant decrease in summer precipitation has been observed across the region, with increasing winter precipitation at western locations since 1970. At western sites, precipitation is highly correlated to the NAO, with positive and negative winter-NAO indices producing anomalies from the long-term winter precipitation average of $112 \%$ and $77 \%$ respectively. The recent winter half-year precipitation increase is concentrated in March and related to a large increase in monthly NAO and the increased occurrence of westerly weather types. The decrease in summer precipitation, however, is caused by both declining receipt from westerly weather types and their decreased occurrence. This is significantly correlated to a decreasing summer index for the NAO. The NAO, the frequency of weather types and precipitation totals are all intimately linked on an annual and monthly time scale. Strong connections between winter precipitation and the NAO may prove very important, particularly in western Yorkshire where most surface water supplies are located. If the NAO can be predicted using sea-surface temperature, it may allow the estimation of winter reservoir replenishment in western Yorkshire a few months in advance. This may provide an important predictor of future hydrological drought episodes and facilitate forward planning and management of water resource systems located in climatologically similar regions of the UK. Copyright (C) 2002 Royal Meteorological Society.
\end{abstract}

KEY WORDS: precipitation; North Atlantic Oscillation; Lamb weather types; water resources; climate change; climatic variability; impacts; UK

\section{INTRODUCTION}

Most general circulation models (GCMs) predict a prominent change of precipitation occurring in high latitudes (e.g. Murphy and Mitchell, 1995; McGuffie et al., 1999) and a move towards an enhanced hydrological cycle (Rowntree et al., 1993). This is also supported by the analyses of precipitation trends (e.g. Bradley et al., 1987; Diaz et al., 1989; Groisman et al., 1999). Studies of the high-latitude Northern Hemisphere suggest a trend towards increased precipitation and enhanced variability (e.g. Easterling et al., 2000), particularly in winter. This enhancement translates to an increase in the proportion of precipitation contributed by extreme, 1-day events. Significant positive trends in intensity have been observed in the UK (Osborn et al., 2000), the USA (Karl and Knight, 1998), Japan (Iwashima and Yamamoto, 1993), Italy (Brunetti et al., 2000) and China (Zhai et al., 1999). The amplification of climatic contrasts across the UK may have severe consequences, particularly in terms of increases in significant flood and drought events, as shown by the 1995 Yorkshire drought.

Variations in precipitation receipt throughout the Northern Hemisphere have been linked to large-scale atmospheric circulation in the form of both the North Atlantic Oscillation (NAO) and weather type descriptors

* Correspondence to: H. J. Fowler, Water Resource Systems Research Laboratory, Department of Civil Engineering, Cassie Building, University of Newcastle, Newcastle upon Tyne NE1 7RU, UK; e-mail: h.j.fowler@ncl.ac.uk 
(e.g. Sweeney and O'Hare, 1992; Wilby et al., 1997). The NAO is a measure of pressure between Iceland and the Azores, and the usual winter index is an average of the December to March values (Jones et al., 1997). Shifts in the NAO can have a profound effect on temperature and precipitation in northern Europe by way of changes in synoptic weather patterns (Hurrell, 1995). Variations in the strength of the NAO have been, particularly, associated with changes in the frequency and magnitude of surface westerlies across northern Europe.

Because of its dominant impact on the weather and climate of Europe, there is a growing interest in quantifying the possible limits of seasonal and interannual predictability of the NAO. Many researchers have attempted to forecast the NAO on a 1 year ahead basis (e.g. Stephenson et al., 2000). Rodwell et al. (1999) linked much of the multiannual to multidecadal variability of the winter NAO over the past 50 years to North Atlantic sea-surface temperatures (SSTs). GCM modelling by Delworth and Mann (2000) then further demonstrated that, for both the model and observations, SST appears to be the primary carrier of the multidecadal signal. It has also recently been proposed that North Atlantic SST patterns show significant multiannual (Sutton and Allen, 1997) and subannual (Hamilton et al., in press) predictability. This may allow the prediction of European winter climate several months in advance (e.g. Hamilton and Saunders, 2000), which will be important in the estimation of winter recharge if relationships can be found between the NAO and precipitation receipt.

This paper examines the relationship between large-scale atmospheric circulation and precipitation in the Yorkshire water resource region, UK, on an annual and seasonal time scale. Annual precipitation receipt varies from just $600 \mathrm{~mm}$ in the eastern lowlands, to over $2000 \mathrm{~mm}$ at high western sites. The main source of precipitation, as elsewhere in the UK, is winds from the westerly quadrant, and these winds provide the majority of annual precipitation to the west of the region. Northerly and easterly winds also bring heavy convective precipitation to the east of the region, particularly in autumn months. Much of Yorkshire is dependent upon a large number of single-season upland reservoirs located in the west of the region. These fill during winter months and are drawn-down in summer months, with relatively little carry-over from one year to the next. If predictions of the winter index of NAO become commonplace and accurate, relationships between the NAO and winter precipitation may provide important information for the prediction of winter recharge in Yorkshire and other regions of the UK.

\section{OBSERVED PRECIPITATION VARIABILITY IN THE YORKSHIRE REGION}

Historical precipitation variability was examined at seven sites in Yorkshire and the surrounding area where long daily records (>50 years) are digitally available (Table I, Figure 1) using data from 1873 to 1998.

Table I. Sites with long daily precipitation records. Annual average rainfall (AAR) and mean proportion of dry days (PD) given for the 1961-90 time period

\begin{tabular}{lllcrrr}
\hline Code & \multicolumn{1}{c}{ Site } & NGR $^{\text {a }}$ & Start year & Altitude (m) & AAR (mm) & PD \\
\hline HR & Hury Reservoir & NY 967193 & 1929 & 263 & 909 & 0.42 \\
BC & Barnard Castle & NZ 056164 & 1926 & 171 & 765 & 0.48 \\
RC & Raby Castle & NZ 128221 & 1929 & 140 & 812 & 0.45 \\
LR & Lockwood Reservoir & NZ 668141 & 1873 & 193 & 803 & 0.45 \\
SC & Scarborough & TA 031883 & 1911 & 52 & 660 & 0.52 \\
MC & Moorland Cottage & SD 807923 & 1936 & 343 & 1939 & 0.41 \\
KB & Kirk Bramwith & SE 618114 & 1891 & 7 & 593 & 0.58 \\
\hline
\end{tabular}

${ }^{a}$ National Grid Reference. 


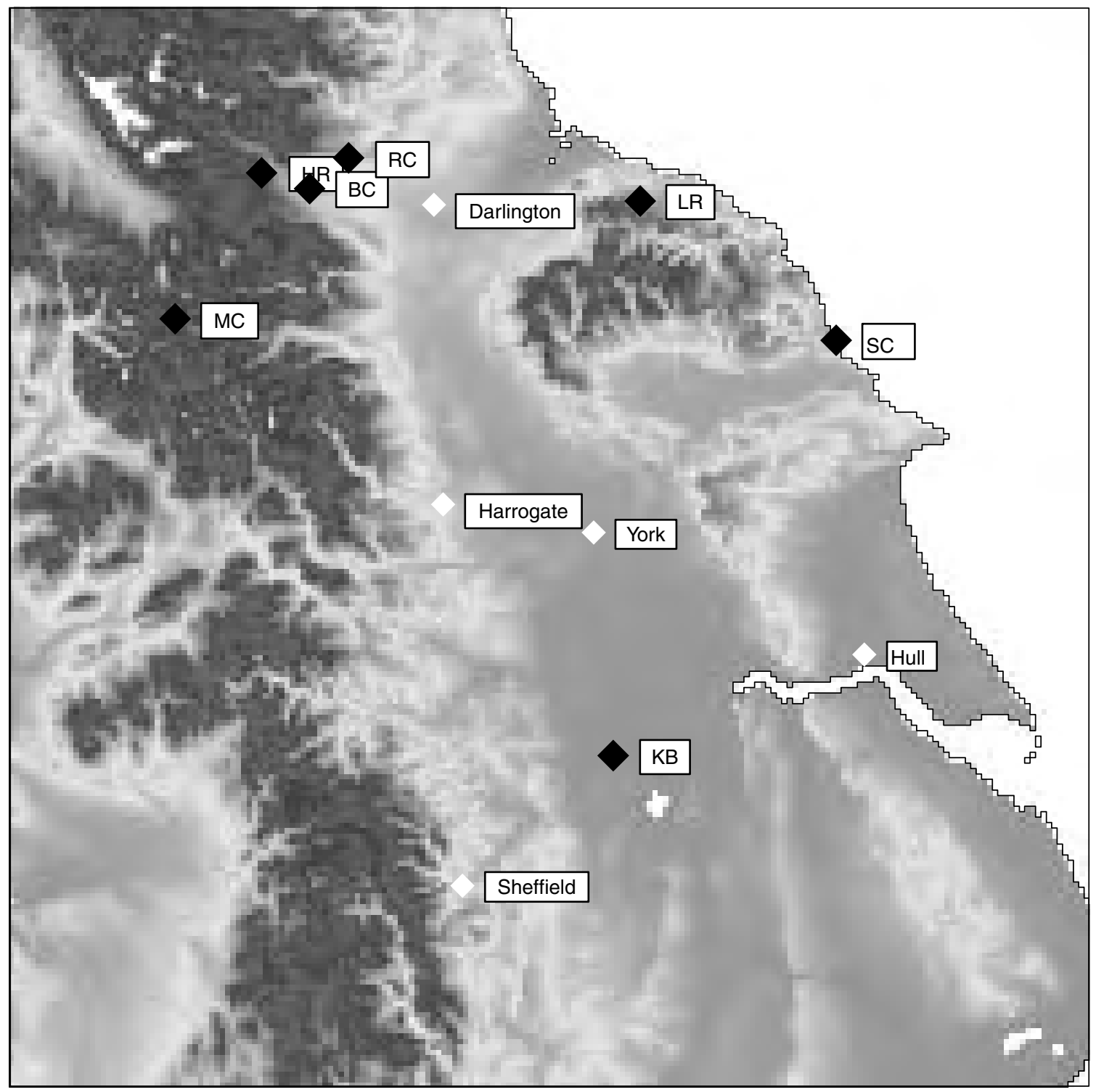

Figure 1. Location of the seven rainfall gauges used in the climatology analysis with an underlay elevation map (dark areas show highest elevation)

\subsection{Fluctuations in daily precipitation amount and proportion of dry days (PD)}

An examination was made of climatological winter (December-February:DJF) and summer (JuneAugust: JJA) precipitation totals and mean PD, where a dry day is defined as having less than $0.2 \mathrm{~mm}$ of precipitation. For each of the seven sites, 20 year centred observed means for precipitation and PD in both summer and winter were computed. These means were expressed as percentage anomalies from the 1937-96 average at each site. The time period from 1937 to 1996 is a period common to all sites that is long enough to average out any weather anomalies.

In winter, most sites presently show a positive precipitation anomaly of between +10 and $+20 \%$ of the 60 year average (Figure 2). This is particularly apparent at the western sites of Hury Reservoir, Barnard Castle and Moorland Cottage, which record an increase in winter precipitation since the late 1970s. At the eastern site of Lockwood Reservoir, however, there is declining winter precipitation from 1930 to 1998. This 

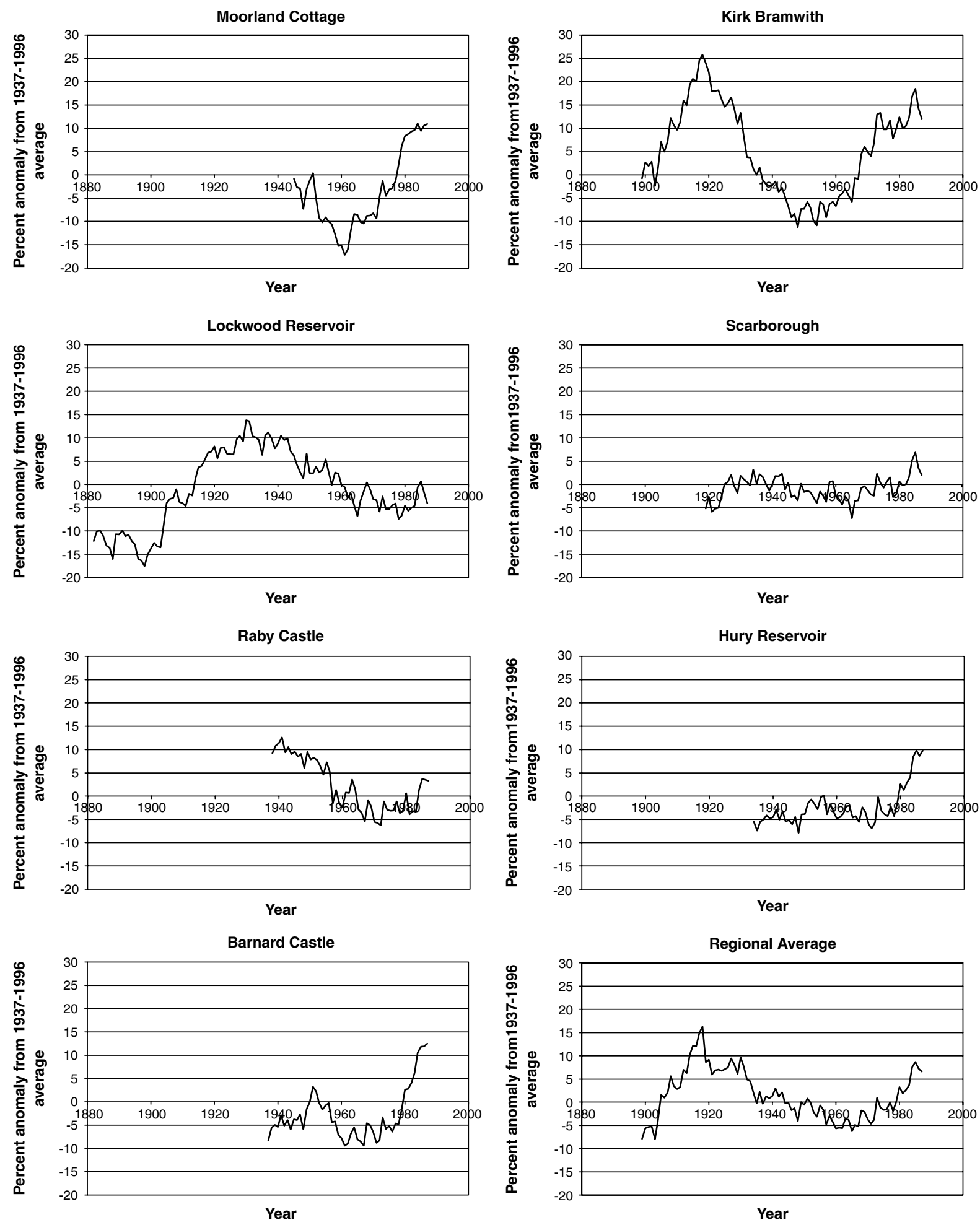

Figure 2. Winter anomalies in precipitation, expressed as percentage anomalies from the 1937-96 average 
suggests that the North York Moors are drier in the winter than they have been since about 1910. A regional average suggests increasing winter rainfall since the 1980s.

In winter, there is also an increasing PD when compared with the 60 year average from 1937 to 1996. The regional trend in PD since 1900 shows three main intervals that correspond well with the timing of the latter three phases of the NAO, as defined by Wilby et al. (1997). There have been four main phases in the NAO during the observed historical records. Prior to the turn of the 20th century the index was close to zero; from 1900 to 1930 there were strong positive anomalies; followed by a low index from 1930 to the 1960s; and since then the index has been strongly positive until recently (Wilby et al., 1997). Regionally, winter PD showed an increase until the 1930s, a decline until the 1970s and then a subsequent increase until the present (Figure 3).

In summer, trends in both precipitation and PD are clearer. Western sites show a recent increase in PD that is unprecedented historically (Figure 4). This is particularly apparent at Moorland Cottage and Raby Castle. The eastern sites document an opposing trend of recently declining PD. However, summer precipitation shows the strongest trend. Figure 5 shows declining totals at all sites since 1960, which can be seen clearly in the regional average, although there has been a recent slight increase due to the wet summers of 1997 and 1998. The severity of the negative anomaly is, in most cases, unprecedented historically and ranges from -5 to $-20 \%$.

A statistical measure for comparing the difference in means between two populations is described by Metcalfe (1994). It is assumed that the samples are independent and follow an approximately normal distribution, i.e. $\bar{X}_{\mathrm{A}} \approx N\left(\mu_{\mathrm{A}}, \sigma_{\mathrm{A}}^{2} / n_{\mathrm{A}}\right)$ and $\bar{X}_{\mathrm{B}} \approx N\left(\mu_{\mathrm{B}}, \sigma_{\mathrm{B}}^{2} / n_{\mathrm{B}}\right)$, where $\bar{X}_{\mathrm{A}}$ and $\bar{X}_{\mathrm{B}}$ represent the distribution of summer precipitation totals from 1960 to 1998 and from 1873 to 1959 respectively. Since the samples are independent, then the distribution for the difference between the two populations approximates to:

$$
\bar{X}_{\mathrm{A}}-\bar{X}_{\mathrm{B}} \approx N\left(\mu_{\mathrm{A}}-\mu_{\mathrm{B}}, \sigma_{\mathrm{A}}^{2} / n_{\mathrm{A}}+\sigma_{\mathrm{B}}^{2} / n_{\mathrm{B}}\right)
$$

The confidence interval for this difference is therefore:

$$
\bar{X}_{\mathrm{A}}-\bar{X}_{\mathrm{B}} \pm z_{\alpha / 2}\left(\sigma_{\mathrm{A}}^{2} / n_{\mathrm{A}}+\sigma_{\mathrm{B}}^{2} / n_{\mathrm{B}}\right)^{1 / 2}
$$

This measure was used to examine the difference in mean precipitation and PD between the time period from 1873 to 1959 and the latter period from 1960 to 1998 (which includes the normal climatological baseline period from 1961 to 1990), using observed summer precipitation and PD rather than the percentage anomaly. Confidence intervals at the $95 \%$ level were produced for the difference in average summer precipitation between the two time periods of 1873-1959 and 1960-98 (Table II). If the two sample periods come from the same population then it would be expected that the confidence intervals would encompass zero, showing no significant change in mean. However, there is evidence of a recent decrease in summer precipitation at Lockwood Reservoir and Raby Castle (both confidence intervals are negative), significant at the 95\% level, and therefore outside two standard deviations of the mean. Although other sites do not show significant relationships, there is skewness towards negative values at all sites. The same analysis was repeated for PD (Table III). There is some evidence that PD has increased during the time period from 1960 to 1998 when compared with 1873-1959, with a significant increase at Raby Castle only, although there is a positive skew at all sites. Unfortunately, the relationships for winter precipitation and PD are not as strong and do not show significant trends.

\subsection{Comparison of monthly precipitation statistics of $P D$ and mean daily precipitation}

Precipitation statistics for the post-1975 period were compared with those of the pre-1975 period for three sites, each of which is representative of a precipitation zone within Yorkshire; see Fowler et al. (2000). Moorland Cottage is representative of the Pennine or western sub-region, Lockwood Reservoir of the North York Moors (northeastern sub-region) and Kirk Bramwith of the southeastern lowlands. Kiely (1999) noted that in Ireland since about 1975 a significant increase in annual precipitation has occurred at west coast sites 

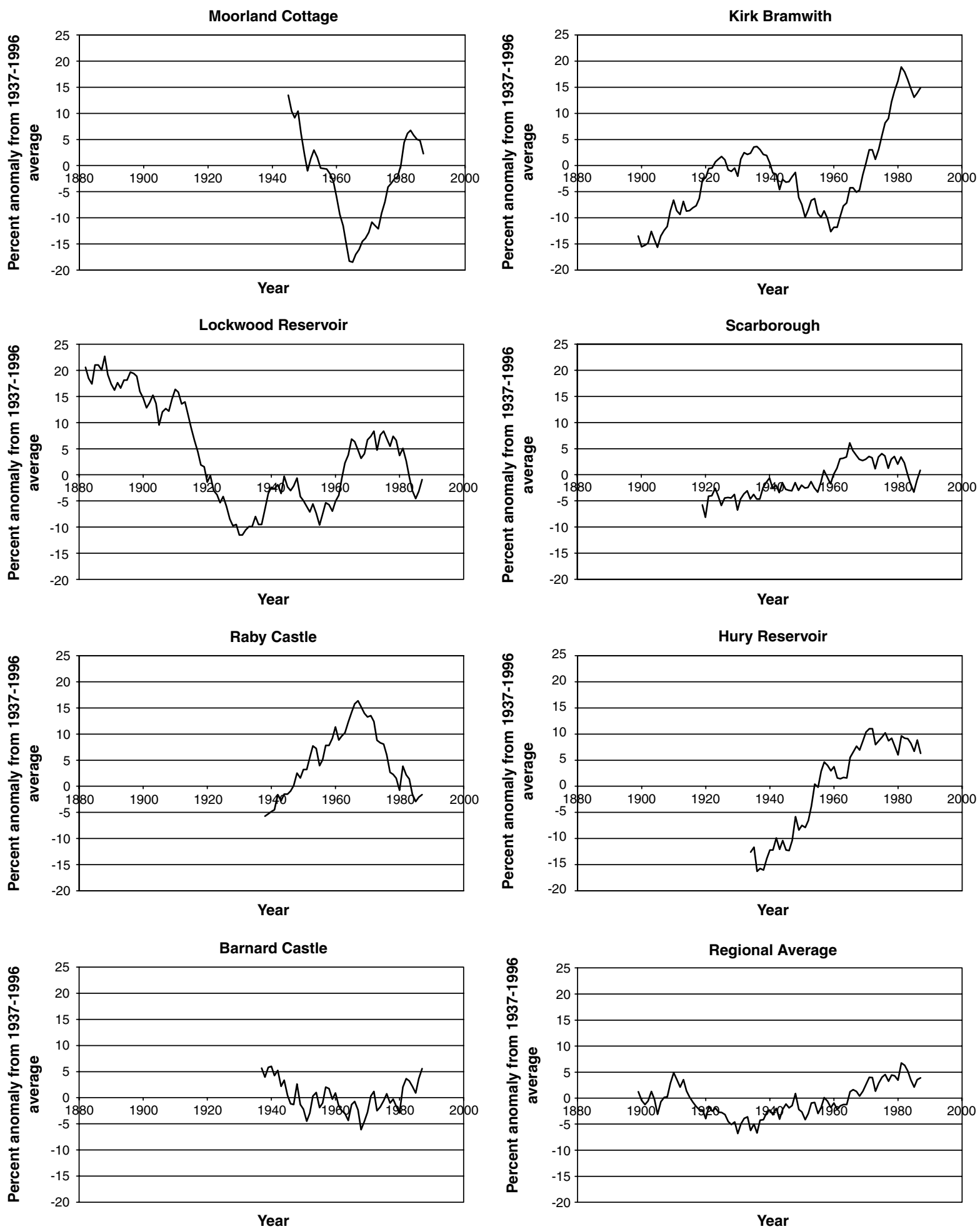

Figure 3. Winter anomalies in PD, expressed as percentage anomalies from the 1937-96 average 

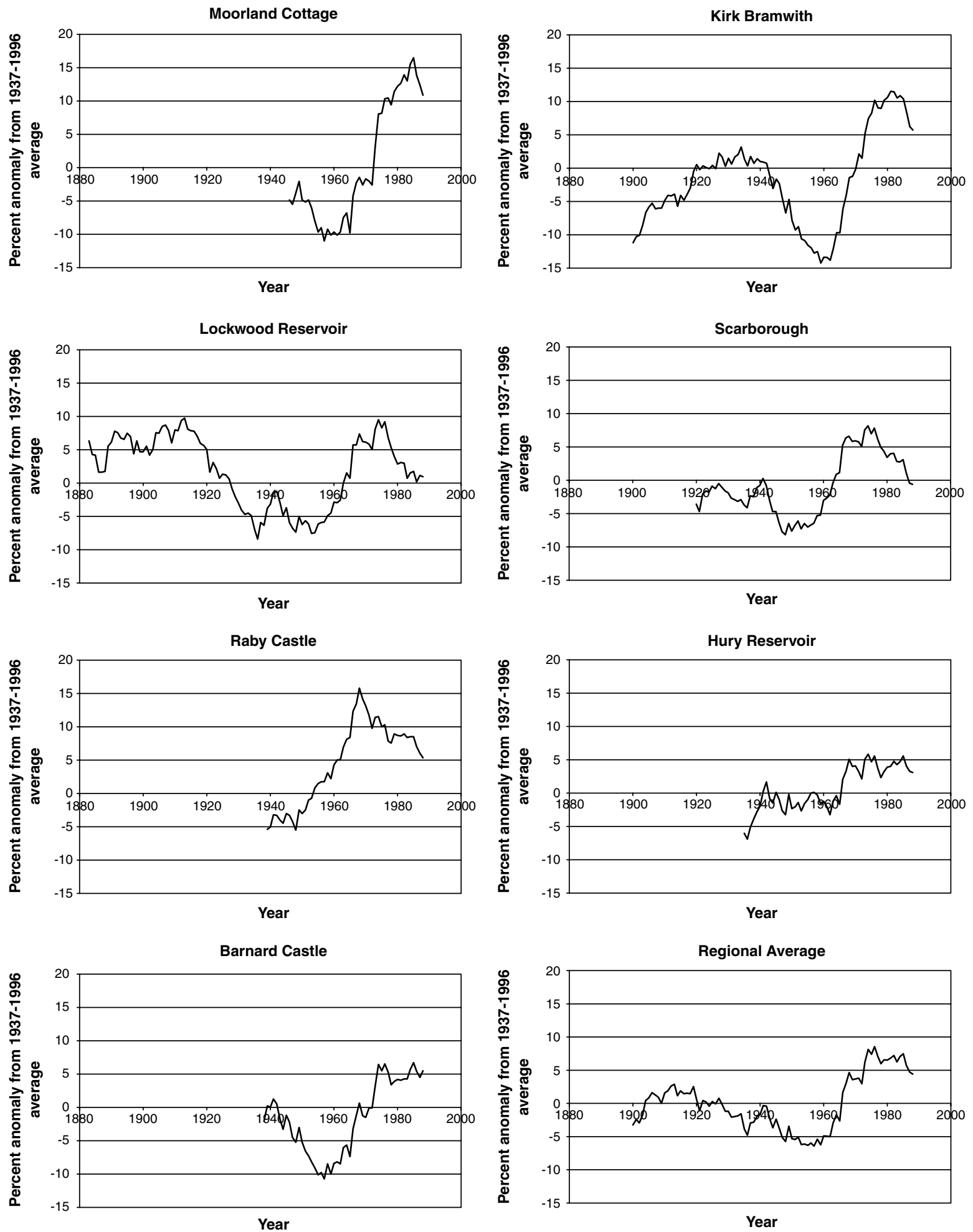

Figure 4. Summer anomalies in PD, expressed as percentage anomalies from the 1937-96 average 

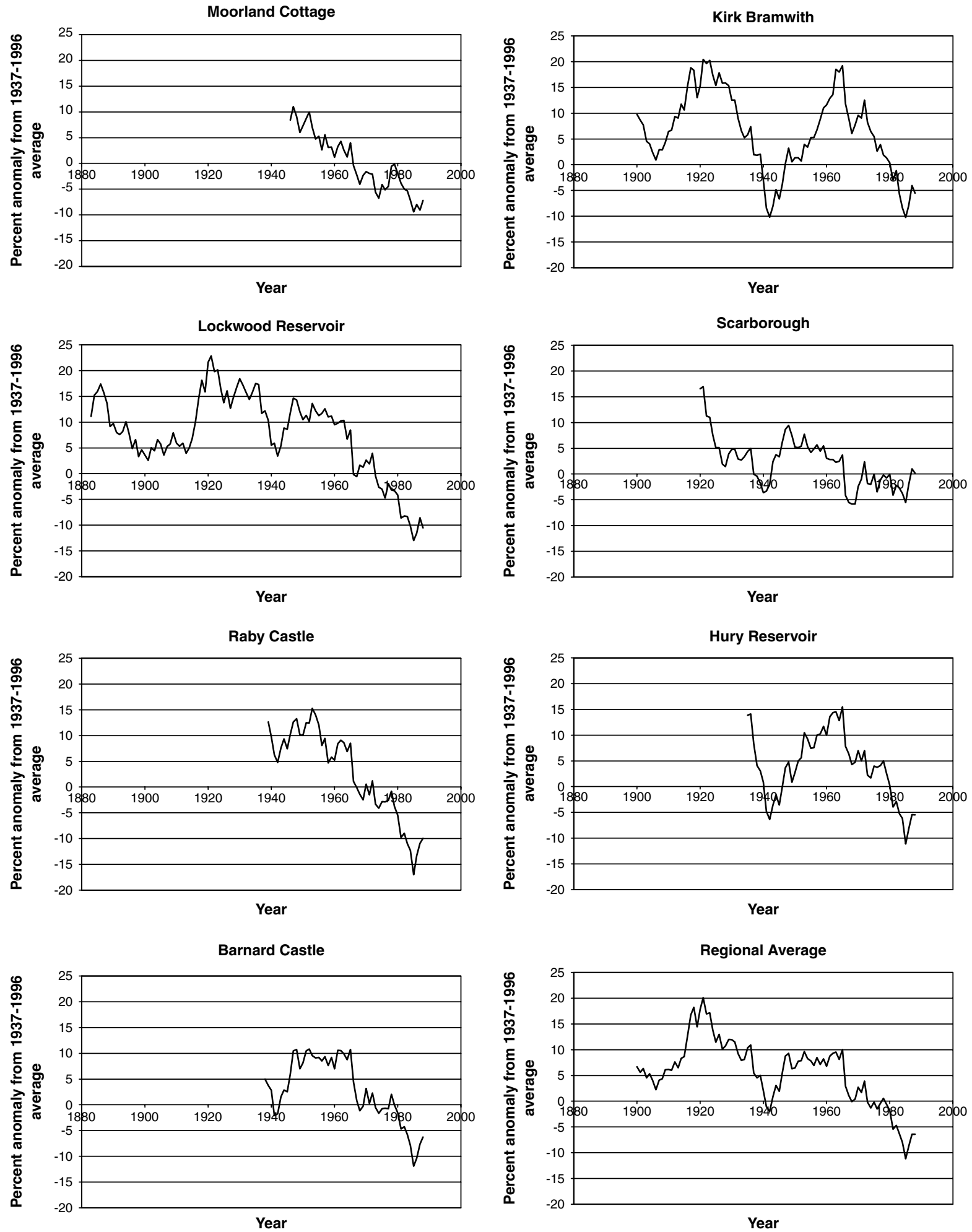

Figure 5. Summer anomalies in precipitation, expressed as percentage anomalies from the 1937-96 average 
Table II. Variables used in analysis of the difference between summer precipitation during the periods from 1873 to 1959 and from 1960 to 1998 and results from the $95 \%$ confidence interval analysis

\begin{tabular}{lccrrrrl}
\hline Site & $\mu_{\mathrm{A}}$ & $\mu_{\mathrm{B}}$ & \multicolumn{1}{c}{$\sigma_{\mathrm{A}}$} & $\sigma_{\mathrm{B}}$ & $n_{\mathrm{A}}$ & $n_{\mathrm{B}}$ & $95 \%$ CI \\
\hline Kirk Bramwith & 166.11 & 175.37 & 58.33 & 61.12 & 39 & 67 & $(-32.7,14.2)$ \\
Moorland Cottage & 376.40 & 424.90 & 113.60 & 135.20 & 38 & 23 & $(-114.5,17.5)$ \\
Scarborough & 160.99 & 177.34 & 54.98 & 56.42 & 39 & 48 & $(-39.9,7.2)$ \\
Lockwood Reservoir & 206.30 & 237.17 & 73.00 & 77.53 & 39 & 86 & $(-59.5,-2.2)$ \\
Raby Castle & 173.27 & 204.40 & 55.17 & 69.10 & 36 & 30 & $(-61.7,-0.5)$ \\
Barnard Castle & 170.27 & 190.80 & 55.77 & 75.10 & 38 & 34 & $(-51.3,10.3)$ \\
Hury Reservoir & 194.09 & 211.50 & 61.24 & 68.00 & 39 & 31 & $(-48.1,13.3)$ \\
\hline
\end{tabular}

Table III. Variables used in analysis of the difference between summer PD during the periods from 1873 to 1959 and from 1960 to 1998 and results from the $95 \%$ confidence interval analysis

\begin{tabular}{lccccccc}
\hline Site & $\mu_{\mathrm{A}}$ & $\mu_{\mathrm{B}}$ & $\sigma_{\mathrm{A}}$ & $\sigma_{\mathrm{B}}$ & $n_{\mathrm{A}}$ & $n_{\mathrm{B}}$ & $95 \%$ CI \\
\hline Kirk Bramwith & 0.61 & 0.58 & 0.129 & 0.106 & 39 & 67 & $(-0.009,0.089)$ \\
Moorland Cottage & 0.47 & 0.44 & 0.127 & 0.114 & 38 & 23 & $(-0.026,0.100)$ \\
Scarborough & 0.60 & 0.56 & 0.105 & 0.093 & 39 & 48 & $(-0.009,0.077)$ \\
Lockwood Reservoir & 0.51 & 0.50 & 0.103 & 0.101 & 39 & 86 & $(-0.030,0.050)$ \\
Raby Castle & 0.60 & 0.52 & 0.103 & 0.105 & 36 & 30 & $(0.028,0.130)$ \\
Barnard Castle & 0.56 & 0.52 & 0.092 & 0.116 & 38 & 34 & $(-0.010,0.090)$ \\
Hury Reservoir & 0.51 & 0.47 & 0.101 & 0.122 & 39 & 31 & $(-0.023,0.085)$ \\
\hline
\end{tabular}

that can be translated into increases in March and October precipitation. On the east coast there has been almost no increase in annual precipitation but the same seasonal increases in March and October, with other months showing a slight decrease (Kiely, 1999).

Figure 6 shows mean daily precipitation for the pre- and post-1975 periods, in addition to the total period of record, for the sites of Moorland Cottage, Lockwood Reservoir and Kirk Bramwith, with standard error bounds. At Moorland Cottage, a similar pattern to that of Ireland emerges. Since 1975, an overall pattern of increasing winter precipitation and decreasing summer precipitation is apparent. There is a prominent increase in March precipitation, but no similar increase in October totals. As a site predominantly affected by westerly weather patterns, Moorland Cottage would be expected to show the same, but weaker, precipitation trends as Ireland. However, no increase is apparent in October.

Both the eastern sites of Lockwood Reservoir and Kirk Bramwith show similar trends in the post1975 period. Prior to 1975, these sites exhibited two precipitation peaks, in August and November, and a precipitation trough in March. The period since 1975 has seen a smoothing of these oscillations at Lockwood Reservoir. At both sites, the July-August peak has disappeared and, instead, a prominent precipitation trough occurs in July. Significantly, March precipitation also increases in the east of the region, whereas in February there is a decline.

Alterations in PD between the two time periods are shown in Figure 7. At Moorland Cottage, a sharp decrease in PD in March accounts for the increased precipitation during this month. The increase in March precipitation is obtained from an increase in wet hours rather than an increase in rainday amount. PD is significantly raised in the summer, however, without a significant concurrent decrease in precipitation. This may suggest an increase in mean rainday amount during the summer and be related to a rise in convective activity. Lockwood Reservoir shows an expected pattern of change in PD, given the previously discussed changes in monthly precipitation. There are increases of PD in the months of August and February, and decreases in March and June. At Kirk Bramwith, there is a significant increase in PD throughout the year, except for the month of March. The reasons behind this are, however, unclear. 


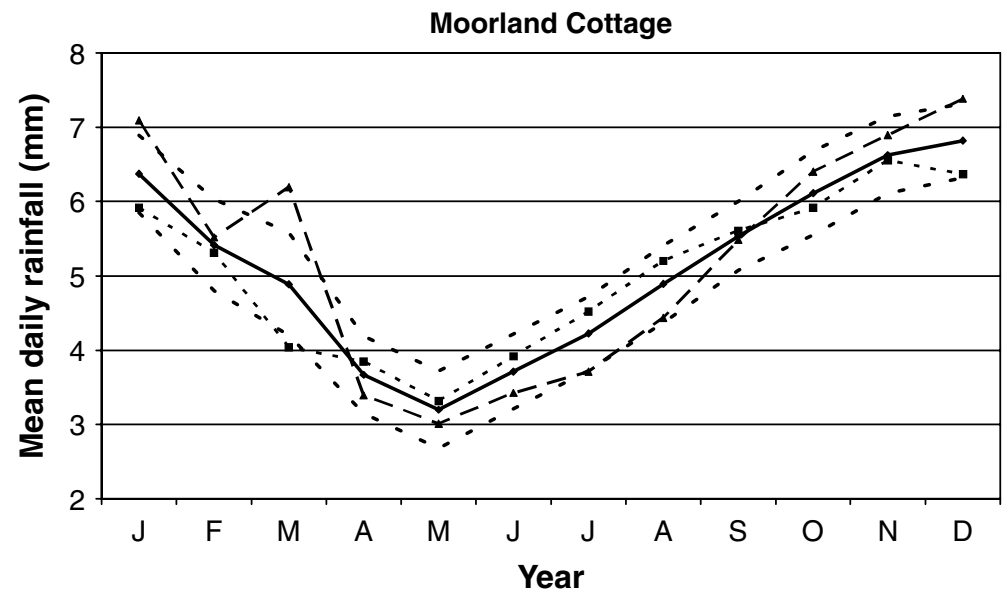

$\rightarrow$-1937-1998 - - Pre-1975 $\rightarrow-$ Post-1975 - - Std Error

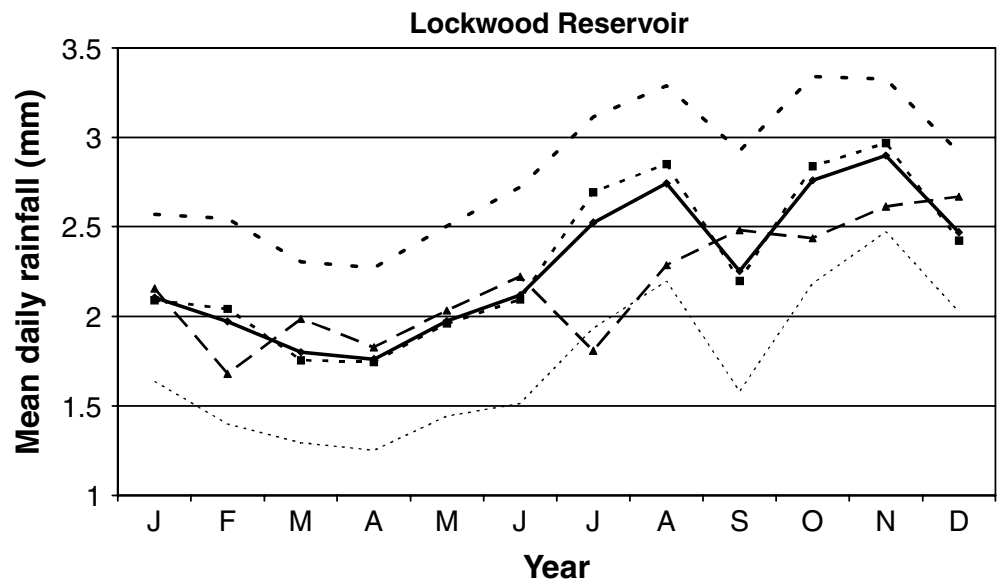

—-1873-1998 - - Pre-1975 $\rightarrow-$ Post-1975 - - Std Error

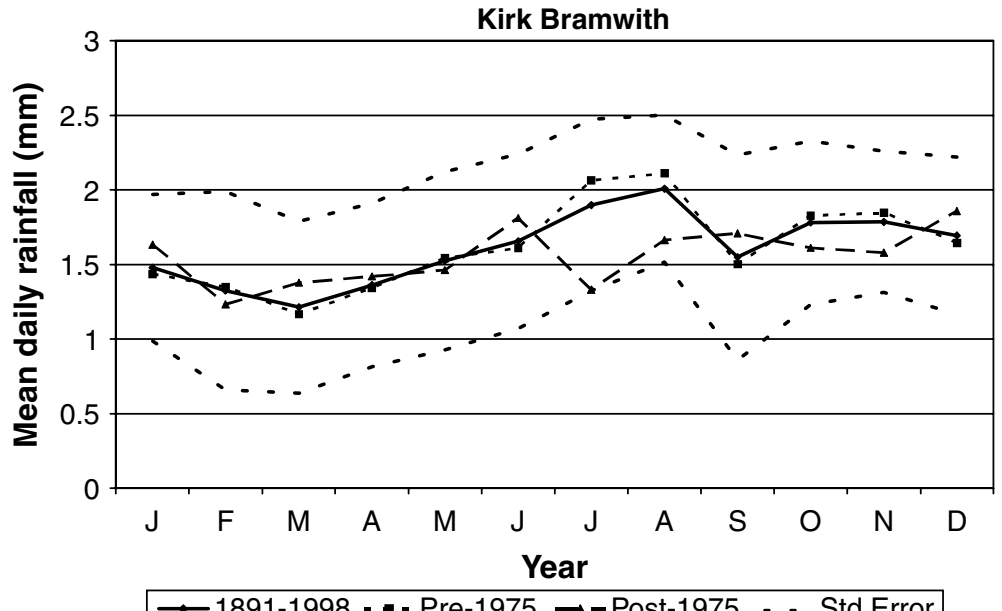

Figure 6. Mean daily rainfall (mm) for the pre- and post-1975 periods at Moorland Cottage, Lockwood Reservoir and Kirk Bramwith 


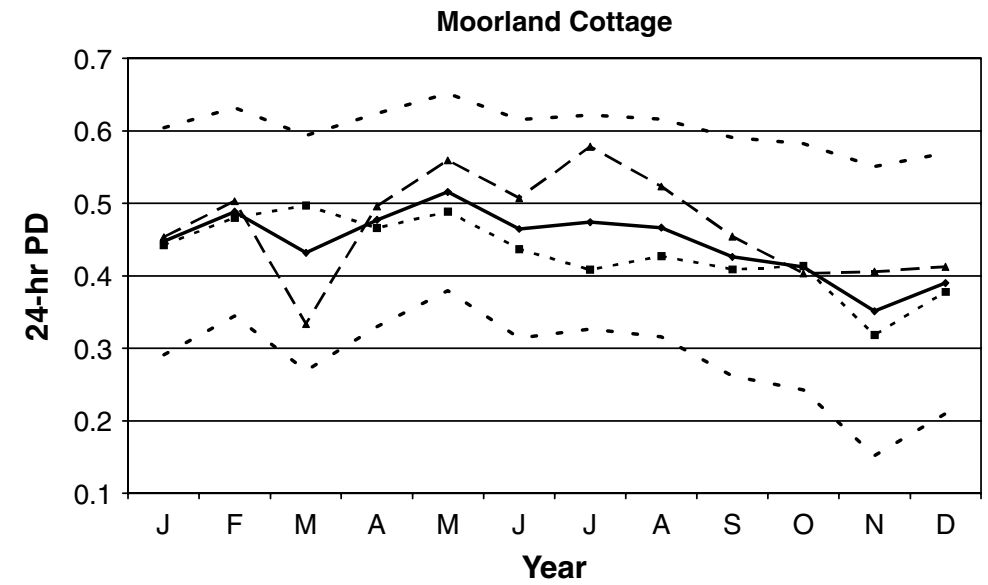

$\longrightarrow$-1937-1998 - - Pre-1975 --Post-1975 - Std Error
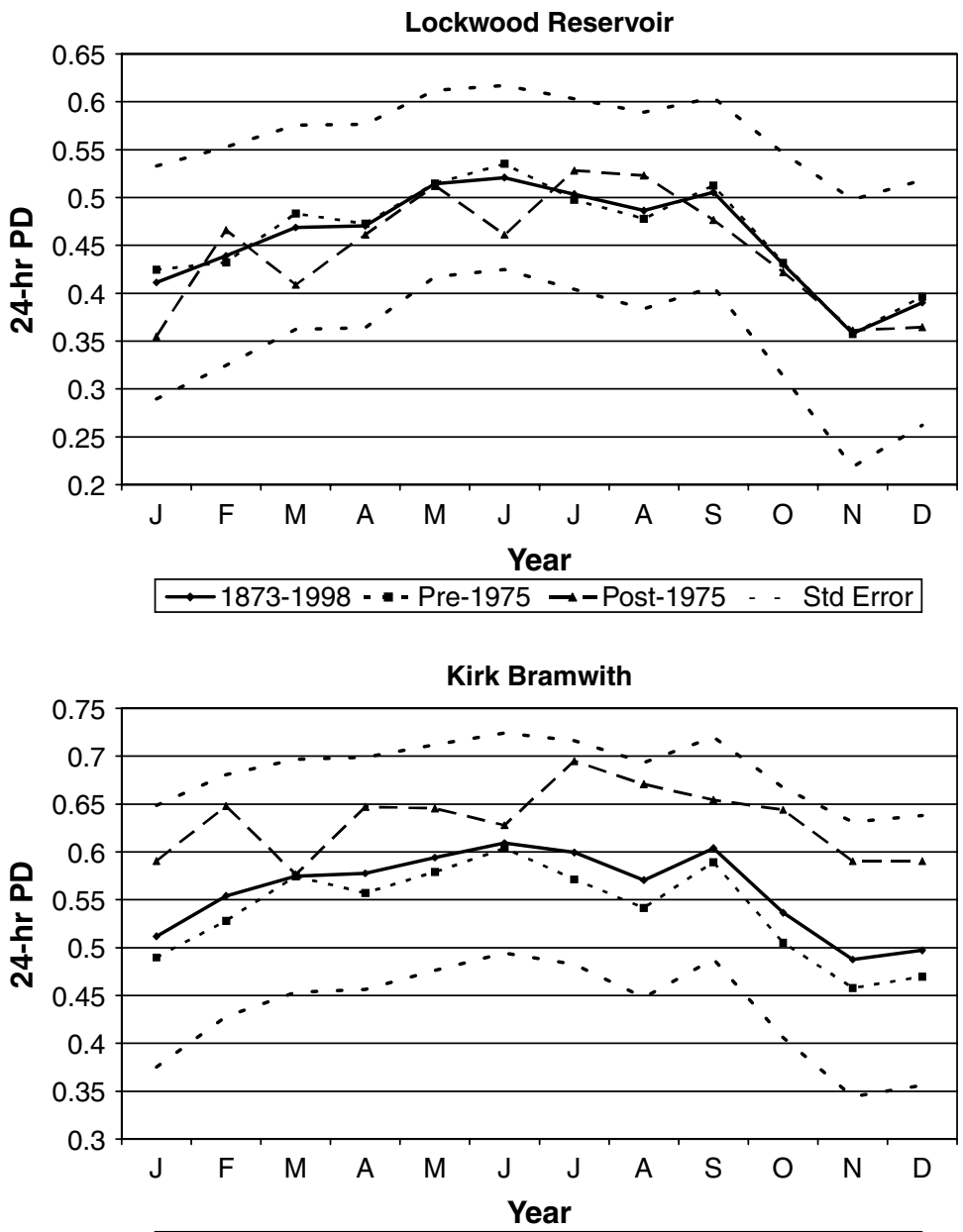

$\rightarrow-1891-1998$ - - Pre-1975 $\rightarrow-$ Post-1975 - Std Error

Figure 7. Proportion of dry days for the pre- and post-1975 periods at Moorland Cottage, Lockwood Reservoir and Kirk Bramwith 


\subsection{Wet and dry spell lengths, and transition probabilities}

There has been a recent increase in the frequency of long dry spells during summer months. At Moorland Cottage prior to 1970, the longest dry spell length was 13 days. This statistic now exceeds 20 days. This is counterbalanced by a decreased frequency of short dry periods and is a noticeable trend at other northern Pennine sites. In spring, there has been an increase in very short-duration dry spells but a decrease in those lasting for longer than about 10 days. In the North York Moors (Lockwood Reservoir) there has been a shift towards longer duration winter wet spells in recent years. Since 1980, there has been a lower proportion of wet spells of from 4 to 9 days in length, but an increase in 10-14 day events. Summer and spring dry spell lengths show no obvious pattern of change.

\subsection{Inter-annual and inter-seasonal variability}

Inter-annual and inter-seasonal variability was examined at the seven sites. Seasonal and annual precipitation totals and PD averages were calculated using data from 1873 to 1998 . These were then ranked to determine the driest and wettest years on record - after Burt et al. (1998).

In Table IV, the regional average places the summer of 1899 as the driest on record, with 1913 placed second, third the summer of 1989, and fourth that of 1995. Recent summers have shown an increased propensity to dryness, with 7 of the last 10 years in the top $20 \%$ of the table. Summer months also show an increased PD, with 7 out of 10 years from 1989 to 1998 ranking in the top half of the table, except 1993. Annually though, the 1990s are not especially dry, due to high winter precipitation totals. Every winter from 1990 to 1996 is wetter than average. The winter of 1994-95 ranks as the wettest winter on record, with the winter of 1993-94 coming fifth. Interestingly, however, some years during the 1990s show a higher proportion of winter dry days than would be expected, given the high precipitation totals. The winters of 1992 and 1993 both have a high proportion of dry days but also high precipitation totals. This suggests that precipitation events were more infrequent but possibly more intense, and that convective activity may be increasing in winter (e.g. Osborn et al., 2000), although it must be noted that this increase in PD could be due to recording errors.

Examination was also made of the winter/summer ratio of precipitation. This produced results that accord with those of other researchers (e.g. Mayes, 1996). The DJF/JJA ratio was the highest of the 123 year record in 1995, and at 4.04, almost double the second-placed 1994. The years of 1991, 1990, 1996 and 1992 are also ranked in the top 13. These results mirror those of Burt et al. (1998) for the sites of Moorhouse (Teesside) and Durham (northeast England). However, since 1996 the DJF/JJA ratio has dropped considerably, as the summers of 1997 and 1998 were very wet, combined with a dry winter in 1996-97. Importantly, most historical drought years are highlighted by the DJF/JJA ratio. Historically, hydrological droughts in Yorkshire appear to be linked to hot and dry summers rather than dry winters; see Fowler and Kilsby (in press).

Site-specific analyses show important regional differences in the inter-annual and inter-seasonal variability of precipitation. In the northern Pennines, at Hury Reservoir and Barnard Castle, the summers from 1990 to 1996 are ranked in the top 30 driest, whereas the 1980s were, on average, wet. The early 1990s also had very wet winters, seen prominently in the extreme DJF/JJA ratio at these two sites for 1995; in both cases more than four times the nearest year. A recent slight increase in annual precipitation in the northern Pennines is due to the increase in winter precipitation. An annual increase in PD, combined with the annual increase in precipitation, suggests a possible increase in precipitation intensity. This may be backed up by the noticeable increase in flooding in the 1990s.

To the east of the region, the summer of 1976 supersedes that of 1995 as the driest summer on record. However, although Lockwood Reservoir in the North York Moors documents an increase in annual precipitation in the 1990s, the coastal site of Scarborough records a decrease. At both sites, the years of 1997 and 1998 are wet years on average but have a high PD.

\subsection{Extreme Events}

Kiely (1999) noted that in Ireland the frequency of extreme value occurrence has increased since 1975. In a similar analysis, but using only daily precipitation, the top 20 and top 100 extreme values in the observed 
Table IV. Top and bottom ten ranked seasonal and annual regional precipitation using data from 1873 to 1998. 1990s years in bold. 1980s years in italic

\begin{tabular}{cccccc}
\hline \multirow{2}{*}{ Rank } & \multicolumn{5}{c}{ Mean daily rainfall (mm) (driest ranks highest) } \\
\cline { 2 - 6 } & Annual & Winter & Spring & Summer & Autumn \\
\hline 1 & 1893 & 1898 & 1893 & 1899 & 1972 \\
2 & 1898 & 1905 & 1929 & 1913 & 1964 \\
3 & 1884 & 1892 & 1938 & 1989 & 1920 \\
4 & 1921 & 1891 & 1896 & $\mathbf{1 9 9 5}$ & 1959 \\
5 & 1929 & 1885 & 1926 & 1884 & 1904 \\
6 & 1905 & 1933 & 1921 & 1887 & 1902 \\
7 & 1955 & 1879 & 1946 & 1919 & 1947 \\
8 & 1902 & 1896 & 1953 & 1935 & $\mathbf{1 9 9 5}$ \\
9 & 1897 & 1927 & 1957 & 1874 & 1937 \\
10 & 1913 & 1908 & 1915 & 1933 & 1915 \\
$\vdots$ & $\vdots$ & $\vdots$ & $\vdots$ & $\vdots$ & $\vdots$ \\
113 & 1980 & 1944 & 1966 & 1938 & 1927 \\
114 & 1939 & 1986 & 1908 & 1967 & 1938 \\
115 & 1903 & 1980 & 1967 & 1909 & 1887 \\
116 & 1965 & 1939 & 1989 & 1958 & 1960 \\
117 & 1880 & 1948 & 1968 & 1880 & 1903 \\
118 & 1954 & 1965 & $\mathbf{1 9 9 4}$ & 1946 & 1935 \\
119 & 1944 & $\mathbf{1 9 9 4}$ & 1937 & 1881 & 1944 \\
120 & 1960 & 1960 & 1977 & 1927 & 1967 \\
121 & 1979 & 1979 & 1979 & 1888 & 1976 \\
122 & 1981 & 1984 & 1981 & 1912 & 1954 \\
123 & 1967 & $\mathbf{1 9 9 5}$ & 1947 & 1931 & 1880 \\
\hline
\end{tabular}

Table V. Distribution of extreme events for the pre- and post-1975 periods at Moorland Cottage, Lockwood Reservoir and Kirk Bramwith. Numbers in parentheses are the expected frequency of extreme events given a uniform spread of extremes across the total time period of record

\begin{tabular}{lcccccc}
\hline & \multicolumn{2}{c}{ Top 20-ranked events } & & \multicolumn{2}{c}{ Top 100-ranked events } \\
\cline { 2 - 3 } \cline { 6 - 7 } & pre-1975 & post-1975 & & pre-1975 & post-1975 \\
\hline Moorland Cottage & 13 & 7 & & 58 & 42 \\
& $(12)$ & $(8)$ & & $(60)$ & $(40)$ \\
Lockwood Reservoir & 17 & 3 & & 82 & 18 \\
Kirk Bramwith & $(16)$ & $(4)$ & & $(80)$ & $(20)$ \\
& 19 & 1 & & 79 & 21 \\
& $(16)$ & $(4)$ & & $(80)$ & $(20)$ \\
\hline
\end{tabular}

record for the three sites of Moorland Cottage, Lockwood Reservoir and Kirk Bramwith were ranked according to severity. Table V shows the distribution of extreme events for the pre-1975 and post-1975 periods. At all sites, the distribution of extreme events has undergone only slight change during the recent time period compared with the expected frequency. At Moorland Cottage and Lockwood Reservoir, there is a similar relationship pre- and post-1975. However, at Kirk Bramwith there has been a slight reduction in extreme events since 1975 when compared with the historical past. 


\section{LINKING PRECIPITATION RECEIPT TO LARGE-SCALE ATMOSPHERIC CIRCULATION}

\subsection{Linking precipitation to the $N A O$}

The mean daily precipitation and PD associated with a positive and negative NAO were calculated for the seven sites shown in Figure 1 in a similar manner to Wilby et al. (1997). The increase in the NAO since the 1960s may be linked to the incidence of higher winter precipitation totals at western sites (Figure 8). However, the opposite trend of declining winter precipitation totals with an increasing NAO is noted at the eastern site of Lockwood reservoir. This evidence supports the conclusions of Wilby et al. (1997) of a negative correlation between winter precipitation and NAO in northeastern England, but a positive correlation in the west.

Table VI compares the mean precipitation amounts arising from a positive and negative NAO. Statistically significant correlations occur most frequently between winter precipitation or PD and the NAO. Winters with positive NAO were wetter than average in the west of Yorkshire and drier than average in the east. Positive precipitation anomalies are greatest at the most western and highest altitude site of Moorland Cottage (112\% of the long-term average and significant at the $95 \%$ level). The precipitation anomaly during positive NAO winters in the west of Yorkshire provides an increase large enough to be noticeable in annual precipitation. In contrast, negative precipitation anomalies are found at eastern sites; for example, both Lockwood Reservoir and Scarborough are $97 \%$ of the long-term average. Conversely, for negative NAO winters, a positive anomaly can be found at eastern sites (107\% and 106\% respectively for Lockwood Reservoir and Scarborough). Western sites, however, show negative precipitation anomalies. This reaches as low as $77 \%$ for Moorland Cottage.

In autumn, a positive NAO causes increased precipitation across Yorkshire and a negative NAO causes a decrease. This is scaled on both westerliness and altitude; sites in the west and at high altitude record

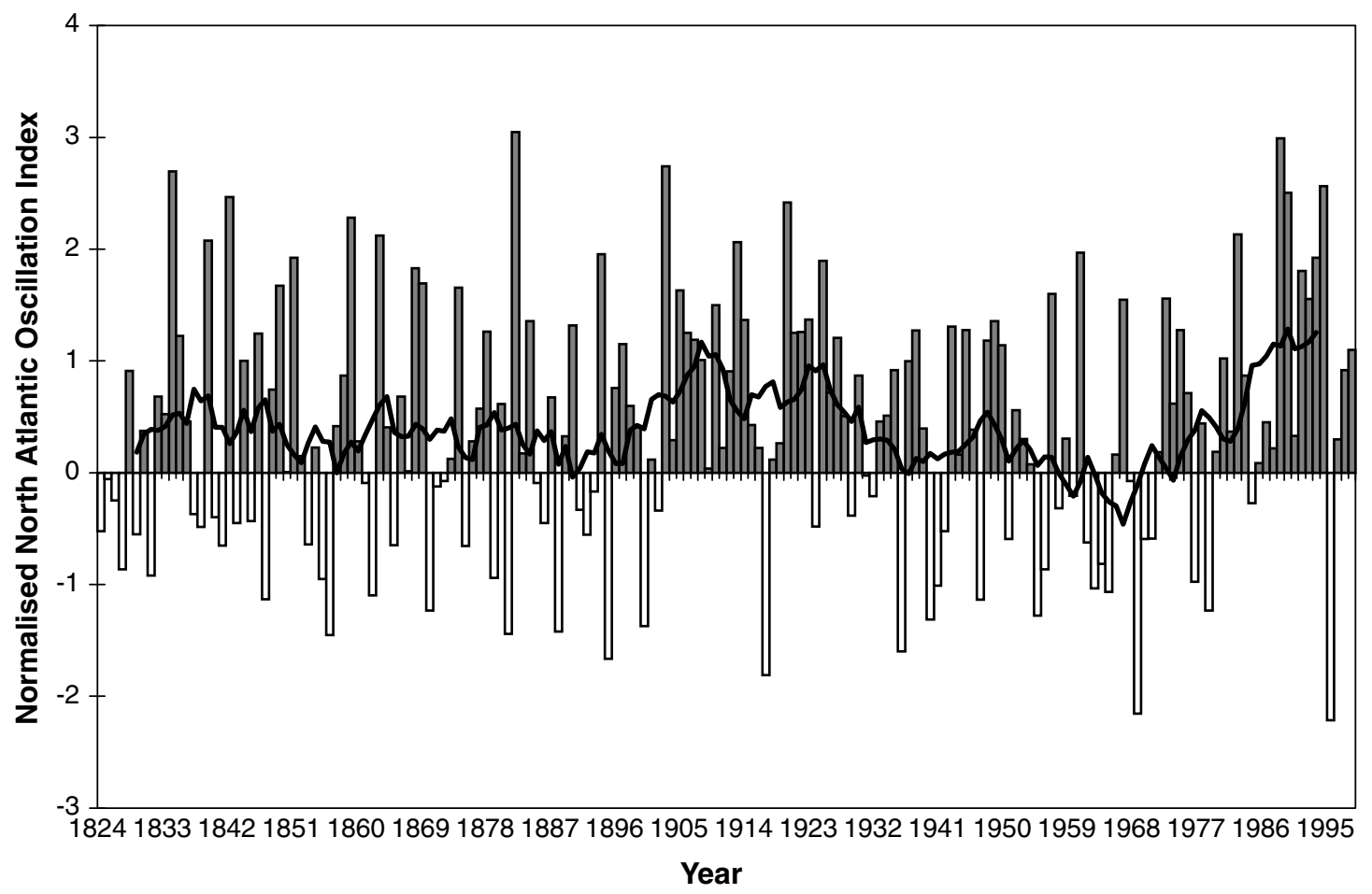

Figure 8. The NAO index for winter (DJFM) as Jones et al. (1997). Imposed upon the yearly values is an 11 year centred moving average that shows the recent increase in the index 
Table VI. Mean rainfall amounts and mean PD both annually and seasonally, associated with positive and negative NAO. Numbers in parentheses indicate the percentage of the long-term average rainfall. Numbers in bold are from significantly different populations when positive and negative NAO values are compared (95\% confidence interval)

\begin{tabular}{|c|c|c|c|c|c|c|c|c|c|c|}
\hline \multirow[t]{2}{*}{ Site } & \multicolumn{2}{|c|}{ Ann-P } & \multicolumn{2}{|c|}{ DJF-P } & \multicolumn{2}{|c|}{ MAM-P } & \multicolumn{2}{|c|}{ JJA-P } & \multicolumn{2}{|c|}{ SON-P } \\
\hline & $+\mathrm{NAO}$ & $-\mathrm{NAO}$ & $+\mathrm{NAO}$ & $-\mathrm{NAO}$ & $+\mathrm{NAO}$ & $-\mathrm{NAO}$ & $+\mathrm{NAO}$ & $-\mathrm{NAO}$ & $+\mathrm{NAO}$ & $-\mathrm{NAO}$ \\
\hline \multicolumn{11}{|c|}{ Mean rainfall amount } \\
\hline $\begin{array}{l}\text { Hury } \\
\text { Reservoir }\end{array}$ & $\begin{array}{c}942 \\
(102)\end{array}$ & $\begin{array}{l}907 \\
(98)\end{array}$ & $\begin{array}{c}289 \\
(107)\end{array}$ & $\begin{array}{l}246 \\
(91)\end{array}$ & $\begin{array}{l}181 \\
(96)\end{array}$ & $\begin{array}{c}206 \\
(109)\end{array}$ & $\begin{array}{c}203 \\
(100)\end{array}$ & $\begin{array}{c}201 \\
(100)\end{array}$ & $\begin{array}{c}278 \\
(104)\end{array}$ & $\begin{array}{l}247 \\
(93)\end{array}$ \\
\hline $\begin{array}{l}\text { Barnard } \\
\text { Castle }\end{array}$ & $\begin{array}{l}786 \\
(100)\end{array}$ & $\begin{array}{l}775 \\
(99)\end{array}$ & $\begin{array}{c}229 \\
(104)\end{array}$ & $\begin{array}{l}203 \\
(93)\end{array}$ & $\begin{array}{l}153 \\
(94)\end{array}$ & $\begin{array}{c}181 \\
(111)\end{array}$ & $\begin{array}{l}179 \\
(99)\end{array}$ & $\begin{array}{c}183 \\
(101)\end{array}$ & $\begin{array}{c}229 \\
(105)\end{array}$ & $\begin{array}{l}199 \\
(91)\end{array}$ \\
\hline $\begin{array}{l}\text { Raby } \\
\text { Castle }\end{array}$ & $\begin{array}{c}746 \\
(100)\end{array}$ & $\begin{array}{c}744 \\
(100)\end{array}$ & $\begin{array}{c}198 \\
(100)\end{array}$ & $\begin{array}{c}200 \\
(101)\end{array}$ & $\begin{array}{l}150 \\
(94)\end{array}$ & $\begin{array}{l}176 \\
(111)\end{array}$ & $\begin{array}{c}188 \\
(100)\end{array}$ & $\begin{array}{l}186 \\
(99)\end{array}$ & $\begin{array}{c}217 \\
(105)\end{array}$ & $\begin{array}{l}185 \\
(90)\end{array}$ \\
\hline $\begin{array}{l}\text { Lockwood } \\
\text { Reservoir }\end{array}$ & $\begin{array}{c}831 \\
(100)\end{array}$ & $\begin{array}{c}842 \\
(101)\end{array}$ & $\begin{array}{l}191 \\
(97)\end{array}$ & $\begin{array}{c}211 \\
(107)\end{array}$ & $\begin{array}{l}167 \\
(98)\end{array}$ & $\begin{array}{l}177 \\
(104)\end{array}$ & $\begin{array}{l}221 \\
(97)\end{array}$ & $\begin{array}{c}242 \\
(107)\end{array}$ & $\begin{array}{c}248 \\
(103)\end{array}$ & $\begin{array}{l}222 \\
(92)\end{array}$ \\
\hline Scarborough & $\begin{array}{c}655 \\
(100)\end{array}$ & $\begin{array}{l}650 \\
(99)\end{array}$ & $\begin{array}{l}163 \\
(97)\end{array}$ & $\begin{array}{c}179 \\
(106)\end{array}$ & $\begin{array}{l}131 \\
(97)\end{array}$ & $\begin{array}{l}145 \\
(107)\end{array}$ & $\begin{array}{c}171 \\
(101)\end{array}$ & $\begin{array}{l}168 \\
(99)\end{array}$ & $\begin{array}{l}186 \\
(104)\end{array}$ & $\begin{array}{l}164 \\
(92)\end{array}$ \\
\hline $\begin{array}{l}\text { Moorland } \\
\text { Cottage }\end{array}$ & $\begin{array}{l}1959 \\
(104)\end{array}$ & $\begin{array}{c}1722 \\
(92)\end{array}$ & $\begin{array}{c}636 \\
(112)\end{array}$ & $\begin{array}{l}442 \\
(77)\end{array}$ & $\begin{array}{l}360 \\
(99)\end{array}$ & $\begin{array}{l}370 \\
(102)\end{array}$ & $\begin{array}{c}394 \\
(100)\end{array}$ & $\begin{array}{l}377 \\
(96)\end{array}$ & $\begin{array}{c}567 \\
(102)\end{array}$ & $\begin{array}{l}505 \\
(91)\end{array}$ \\
\hline $\begin{array}{l}\text { Kirk } \\
\text { Bramwith }\end{array}$ & $\begin{array}{l}585 \\
(99)\end{array}$ & $\begin{array}{c}598 \\
(102)\end{array}$ & $\begin{array}{l}136 \\
(100)\end{array}$ & $\begin{array}{l}134 \\
(99)\end{array}$ & $\begin{array}{l}125 \\
(99)\end{array}$ & $\begin{array}{c}132 \\
(105)\end{array}$ & $\begin{array}{l}167 \\
(97)\end{array}$ & $\begin{array}{c}182 \\
(106)\end{array}$ & $\begin{array}{l}155 \\
(101)\end{array}$ & $\begin{array}{l}152 \\
(99)\end{array}$ \\
\hline \multicolumn{11}{|l|}{ Mean PD } \\
\hline $\begin{array}{l}\text { Hury } \\
\quad \text { Reservoir }\end{array}$ & $\begin{array}{c}0.4 \\
(101)\end{array}$ & $\begin{array}{l}0.4 \\
(97)\end{array}$ & $\begin{array}{l}0.3 \\
(97)\end{array}$ & $\begin{array}{c}0.4 \\
(103)\end{array}$ & $\begin{array}{c}0.5 \\
(\mathbf{1 0 4})\end{array}$ & $\begin{array}{c}0.4 \\
(91)\end{array}$ & $\begin{array}{c}0.5 \\
(101)\end{array}$ & $\begin{array}{l}0.5 \\
(98)\end{array}$ & $\begin{array}{l}0.4 \\
(99)\end{array}$ & $\begin{array}{c}0.4 \\
(102)\end{array}$ \\
\hline $\begin{array}{l}\text { Barnard } \\
\text { Castle }\end{array}$ & $\begin{array}{c}0.5 \\
(100)\end{array}$ & $\begin{array}{c}0.5 \\
(100)\end{array}$ & $\begin{array}{c}0.4 \\
(98)\end{array}$ & $\begin{array}{c}0.4 \\
(104)\end{array}$ & $\begin{array}{c}\mathbf{0 . 5} \\
(\mathbf{1 0 3})\end{array}$ & $\begin{array}{c}0.5 \\
(94)\end{array}$ & $\begin{array}{c}0.5 \\
(101)\end{array}$ & $\begin{array}{c}0.5 \\
(99)\end{array}$ & $\begin{array}{c}0.4 \\
(97)\end{array}$ & $\begin{array}{c}0.5 \\
(105)\end{array}$ \\
\hline $\begin{array}{l}\text { Raby } \\
\text { Castle }\end{array}$ & $\begin{array}{c}0.5 \\
(101)\end{array}$ & $\begin{array}{l}0.5 \\
(99)\end{array}$ & $\begin{array}{c}0.4 \\
(98)\end{array}$ & $\begin{array}{c}0.5 \\
(104)\end{array}$ & $\begin{array}{c}\mathbf{0 . 6} \\
(\mathbf{1 0 4})\end{array}$ & $\begin{array}{r}0.5 \\
(93)\end{array}$ & $\begin{array}{c}0.6 \\
(101)\end{array}$ & $\begin{array}{c}0.6 \\
(99)\end{array}$ & $\begin{array}{c}0.5 \\
(98)\end{array}$ & $\begin{array}{c}0.5 \\
(104)\end{array}$ \\
\hline $\begin{array}{l}\text { Lockwood } \\
\text { Reservoir }\end{array}$ & $\begin{array}{c}0.5 \\
(101)\end{array}$ & $\begin{array}{l}0.4 \\
(98)\end{array}$ & $\begin{array}{c}0.4 \\
(101)\end{array}$ & $\begin{array}{c}0.4 \\
(97)\end{array}$ & $\begin{array}{c}0.5 \\
(101)\end{array}$ & $\begin{array}{l}0.5 \\
(97)\end{array}$ & $\begin{array}{c}0.5 \\
(102)\end{array}$ & $\begin{array}{c}0.5 \\
(96)\end{array}$ & $\begin{array}{c}0.4 \\
(99)\end{array}$ & $\begin{array}{c}0.4 \\
(102)\end{array}$ \\
\hline Scarborough & $\begin{array}{c}0.5 \\
(100)\end{array}$ & $\begin{array}{l}0.5 \\
(99)\end{array}$ & $\begin{array}{c}0.4 \\
(101)\end{array}$ & $\begin{array}{l}0.4 \\
(97)\end{array}$ & $\begin{array}{c}0.6 \\
(102)\end{array}$ & $\begin{array}{l}0.5 \\
(96)\end{array}$ & $\begin{array}{c}0.6 \\
(101)\end{array}$ & $\begin{array}{c}0.6 \\
(98)\end{array}$ & $\begin{array}{l}0.5 \\
(98)\end{array}$ & $\begin{array}{c}0.5 \\
(105)\end{array}$ \\
\hline $\begin{array}{r}\text { Moorland } \\
\text { Cottage }\end{array}$ & $\begin{array}{c}0.4 \\
(100)\end{array}$ & $\begin{array}{c}0.4 \\
(100)\end{array}$ & $\begin{array}{c}\mathbf{0 . 4} \\
(\mathbf{9 4})\end{array}$ & $\begin{array}{c}0.5 \\
(113)\end{array}$ & $\begin{array}{c}0.5 \\
(102)\end{array}$ & $\begin{array}{c}0.4 \\
(95)\end{array}$ & $\begin{array}{c}0.5 \\
(98)\end{array}$ & $\begin{array}{c}0.5 \\
(98)\end{array}$ & $\begin{array}{c}0.4 \\
(98)\end{array}$ & $\begin{array}{c}0.4 \\
(99)\end{array}$ \\
\hline $\begin{array}{l}\text { Kirk } \\
\text { Bramwith }\end{array}$ & $\begin{array}{c}0.6 \\
(101)\end{array}$ & $\begin{array}{l}0.5 \\
(98)\end{array}$ & $\begin{array}{l}0.5 \\
(99)\end{array}$ & $\begin{array}{c}0.5 \\
(100)\end{array}$ & $\begin{array}{c}0.6 \\
(101)\end{array}$ & $\begin{array}{c}0.6 \\
(98)\end{array}$ & $\begin{array}{c}0.6 \\
(102)\end{array}$ & $\begin{array}{c}0.6 \\
(96)\end{array}$ & $\begin{array}{c}0.5 \\
(101)\end{array}$ & $\begin{array}{c}0.5 \\
(100)\end{array}$ \\
\hline
\end{tabular}

greater precipitation reductions than those further east and at lower altitude. The opposite effect occurs in spring, with positive NAO producing precipitation reductions and a negative NAO producing precipitation increases. These increases can be as high as $111 \%$ and are greater in north Yorkshire. In summer, there are no obvious patterns except for an increase in mean daily precipitation under a negative NAO at some of the eastern Yorkshire sites. The records from these sites stretch back into the last century, showing a trend to drier summers in recent years under a highly positive NAO.

Table VI also compares the mean PD occurring due to positive and negative NAO. The most prominent PD anomaly is in winter at Moorland Cottage. An increase in PD (113\% of the long-term average and significant 
Table VII. Weather-type cluster definitions for the three weather states in both 'summer' and 'winter'

\begin{tabular}{ll}
\hline Weather state & \multicolumn{1}{c}{ Objective Lamb weather type } \\
\hline Anticyclonic (A) & A, AE, ASE, AS, ASW \\
Northerly (N) & AN, ANE, N, NE, CN, CNE, E, SE, CE, CSE \\
Westerly (W) & AW, ANW, S, SW, W, NW, C, CS, CSW, CW, CNW \\
\hline
\end{tabular}

at the $95 \%$ level) is caused by a negative NAO, and vice versa. This increased PD is also recorded at other westerly sites, whereas easterly sites record decreased PD during a negative NAO. This suggests that there are increased winter raindays in the west during a positive phase of the NAO, as would be expected. However, there is no concurrent decrease in annual PD at Moorland Cottage, although there was an increase in annual mean daily precipitation. This may imply increased intensity of precipitation at western sites, particularly in winter, under a positive NAO.

A comparison of spring and autumn PD anomalies reveals a similar relationship to that of mean daily precipitation. A positive NAO causes increased PD in spring, when compared with the long-term average, but a decreased PD in autumn months. The opposite relationship is found during a negative NAO. This relationship is especially prominent in northern Yorkshire and County Durham during spring months, where at all three sites of Hury Reservoir, Barnard Castle and Raby Castle a significant relationship at the 95\% level is recorded.

\subsection{Linking weather types to precipitation and the NAO}

Previous work by Fowler et al. (2000) has grouped the objective weather types of Jenkinson and Collinson (1977), updated by Jones et al. (1993), into three distinct weather states. In Yorkshire, the major sources of precipitation can be split into two: the northerly and westerly weather states, with an additional weather state that is dry across the region and encompasses the majority of the anticyclonic types (Table VII). It may be noted that, in meteorological terms, these may roughly be defined as blocking (anticyclonic), zonal (westerly) and meridional (northerly). The weather types within the 'westerly' state supply the west of the

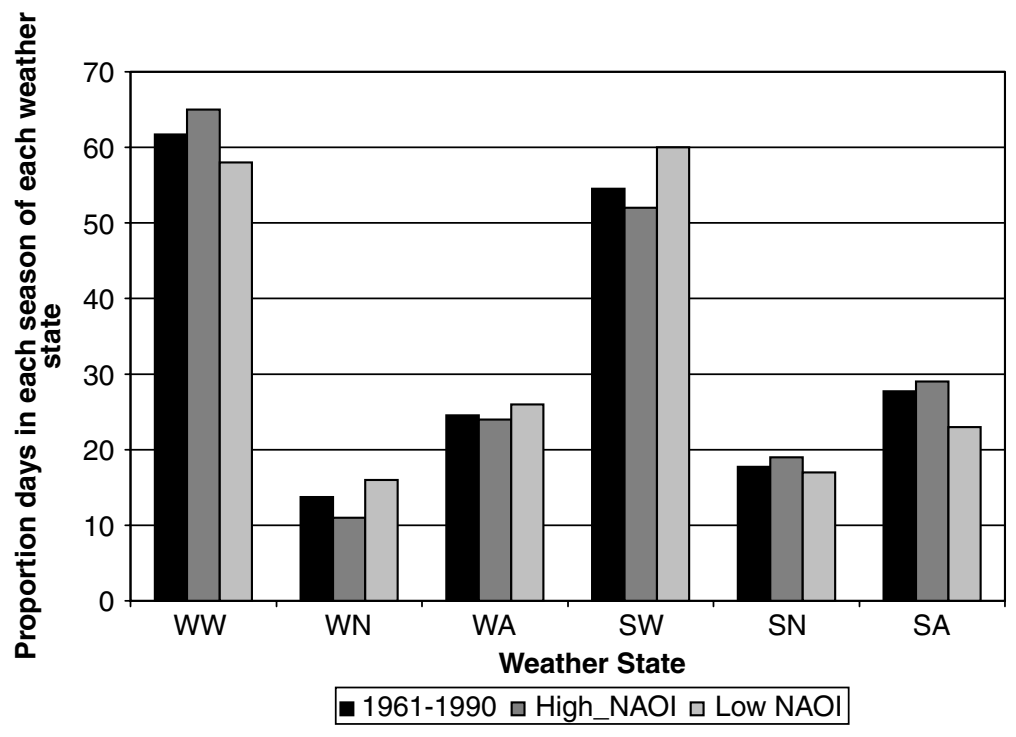

Figure 9. Frequency of occurrence of a weather state in a low- and high-NAO period compared with the 1961-90 average 
region with precipitation, whereas the 'northerly' state provides precipitation to the north and east. These are further delineated into 'winter' and 'summer' states; 'winter' defined as October to March, and 'summer' as April to September. The notation for each weather state is therefore: SA (summer anticyclonic), WA (winter anticyclonic), WW (winter westerly), SW (summer westerly), WN (winter northerly) and SN (summer northerly).

In Fowler et al. (2000), Yorkshire is divided into three climatogically distinct sub-regions using daily data at 150 sites. These are modelled using a representative site for each sub-region. The sites used are Moorland Cottage (Pennine sub-region), Lockwood Reservoir (North York Moors) and Kirk Bramwith (southeastern lowlands). The clustering and precipitation zonation are further explained in Fowler et al. (2000).

The correlation between a winter and summer NAO index and weather state frequency was examined by Fowler et al. (2000). The winter index is, as previously defined, the December to March average of pressure differences and the summer index is defined as the May to July average. A clear correlation was found between the NAO indices and the frequency of weather states, especially the anticyclonic and westerly types. A strong inverse correlation was observed between the SW and SA, and the WW and WA weather states respectively. During a high winter-NAO period, such as from 1980 to 1990 , there is an increased frequency of the WW and SA weather states, to the detriment of the SW and WA weather states. In a low winter-NAO period, such as $1960-70$, the reverse situation occurs. This is shown in Figure 9.

The NAO and precipitation were then linked on a monthly time scale, in a similar way to Kiely (1999). Significant correlations can be found in Table VIII. It is notable that a high correlation is obtained between monthly NAO and precipitation for winter months at Moorland Cottage, but a very low correlation in summer. Perhaps significantly, the March and October correlation statistics are low compared with other winter months. This may imply changing seasonality during these months. At the eastern sites of Lockwood Reservoir and Kirk Bramwith high correlations are obtained only in July (positive) and October (negative). The declining NAO in July has contributed to reduced July precipitation totals at both sites.

The further step was made to link the monthly occurrence of the three weather states to the monthly NAO index. Table IX shows that the relationship between seasonal indices of the NAO and the occurrence of different weather states is also strong at the monthly level. A positive relationship is found between monthly NAO and the occurrence of the westerly weather state in all months. The correlation is particularly strong in the month of March, at 0.932, and may account for the increased precipitation totals during March in Ireland discussed by Kiely (1999). The anticyclonic and northerly weather states show a negative correlation

Table VIII. Correlation coefficients between monthly precipitation and monthly-NAO at the three sites (bold figures indicate a significant correlation at the $95 \%$ level)

\begin{tabular}{lcrr}
\hline Month & Moorland Cottage & Lockwood Reservoir & Kirk Bramwith \\
\hline J & $\mathbf{0 . 7 2}$ & -0.14 & 0.07 \\
F & $\mathbf{0 . 6 9}$ & $\mathbf{- 0 . 2 9}$ & -0.06 \\
M & $\mathbf{0 . 3 5}$ & $\mathbf{0 . 2 2}$ & $\mathbf{0 . 3 9}$ \\
A & $\mathbf{0 . 5 9}$ & $\mathbf{- 0 . 4 9}$ & $\mathbf{- 0 . 2 5}$ \\
M & 0.26 & $\mathbf{- 0 . 2 1}$ & $\mathbf{0 . 2 3}$ \\
J & 0.11 & -0.12 & $\mathbf{- 0 . 5 1}$ \\
J & 0.22 & $\mathbf{0 . 6 7}$ & $\mathbf{0 . 5 6}$ \\
A & 0.13 & 0.06 & 0.09 \\
S & $\mathbf{0 . 5 2}$ & -0.18 & $\mathbf{- 0 . 3 2}$ \\
O & $\mathbf{0 . 4 7}$ & $-\mathbf{0 . 6 1}$ & $\mathbf{- 0 . 5 3}$ \\
N & $\mathbf{0 . 5 3}$ & -0.20 & -0.16 \\
D & $\mathbf{0 . 7 1}$ & -0.04 & $\mathbf{0 . 4 4}$ \\
\hline
\end{tabular}


Table IX. Correlation coefficients between monthly NAO and the occurrence of the three weather states: $\mathrm{W}=$ westerly, $\mathrm{A}=$ anticyclonic, and $\mathrm{N}=$ northerly (bold figures indicate a significant correlation at the $95 \%$ level) on an interannual basis

\begin{tabular}{lrrr}
\hline Month & \multicolumn{3}{c}{ Weather state } \\
\cline { 2 - 4 } & \multicolumn{1}{c}{$\mathrm{A}$} & $\mathrm{N}$ & $\mathrm{W}$ \\
\hline $\mathrm{J}$ & $\mathbf{- 0 . 2 0}$ & $\mathbf{- 0 . 8 2}$ & $\mathbf{0 . 5 8}$ \\
F & $\mathbf{- 0 . 3 4}$ & $\mathbf{- 0 . 6 2}$ & $\mathbf{0 . 6 4}$ \\
M & $\mathbf{- 0 . 8 5}$ & $\mathbf{- 0 . 7 5}$ & $\mathbf{0 . 9 3}$ \\
A & 0.02 & $\mathbf{- 0 . 7 6}$ & $\mathbf{0 . 7 1}$ \\
M & $-\mathbf{0 . 4 1}$ & $\mathbf{- 0 . 6 5}$ & $\mathbf{0 . 7 1}$ \\
J & 0.12 & $\mathbf{- 0 . 7 1}$ & $\mathbf{0 . 7 8}$ \\
J & $\mathbf{- 0 . 7 1}$ & 0.00 & $\mathbf{0 . 6 3}$ \\
A & -0.33 & $-\mathbf{0 . 3 8}$ & $\mathbf{0 . 4 0}$ \\
S & $\mathbf{- 0 . 4 1}$ & $\mathbf{- 0 . 3 1}$ & $\mathbf{0 . 5 0}$ \\
O & $\mathbf{- 0 . 3 0}$ & $\mathbf{- 0 . 6 3}$ & $\mathbf{0 . 5 8}$ \\
N & $\mathbf{- 0 . 2 7}$ & $\mathbf{- 0 . 5 4}$ & $\mathbf{0 . 5 6}$ \\
D & $\mathbf{0 . 2 0}$ & $\mathbf{- 0 . 5 3}$ & $\mathbf{0 . 2 8}$ \\
& & &
\end{tabular}

for the majority of months. Again, particularly high negative correlations are found during the month of March.

Kiely (1999) speculated that increases in westerly weather type occurrence in March and October since 1975 had caused the increase in precipitation during these two months. It can be observed in Figure 10, however, that the NAO has in fact been decreasing in October since the mid-1980s. Therefore, an increase in westerly weather state occurrence is an unlikely explanation for the increase in precipitation. Figure 11 shows the frequency of occurrence of the westerly weather state in March and October. In March, the westerly weather state has increased in frequency from 16 to 24 days on average since 1975. In October, there has been a fluctuation around a frequency of 19 days since the 1940s and, indeed, a recent decline since the mid-1980s to a current frequency of about 17 days. Therefore, in March an increase in westerly weather type occurrence is a good explanation for increased precipitation, but in October an increase in wet day amount for the westerly weather state or an increase in convective activity are more plausible explanations. Indeed, a similar phenomenon noted at eastern sites in the months of September and October is related to increased convective precipitation arising from a northerly and easterly maritime source. Increased convective precipitation at western sites from a westerly maritime source could similarly occur during the month of October, when SSTs are high, and increased evaporation causes increased convective storms. The non-frontal nature of such an increase means that increased precipitation in coastal areas would not be seen further inland, such as in the Pennines.

Since strong relationships were found between the monthly NAO and the three weather states, it is likely that similar links between weather states and monthly precipitation totals exist. These can be found in Table X. A strong positive relationship exists between precipitation at Moorland Cottage and the frequency of the westerly weather state, as would be expected. At the two eastern sites all significant correlations between precipitation and westerly weather state occurrence are positive. Interestingly, positive correlations are also observed between the northerly weather state and precipitation totals at eastern sites during spring and autumn months. All sites exhibit a strong positive correlation between westerly weather state frequency and precipitation during the month of March.

Investigation was made into the effect of high and low winter-NAO phases upon the mean daily precipitation, PD and variability of precipitation for the six weather states at Moorland Cottage (Figure 12). The average daily precipitation receipt for a particular weather group was found to be unstable temporally, and this 

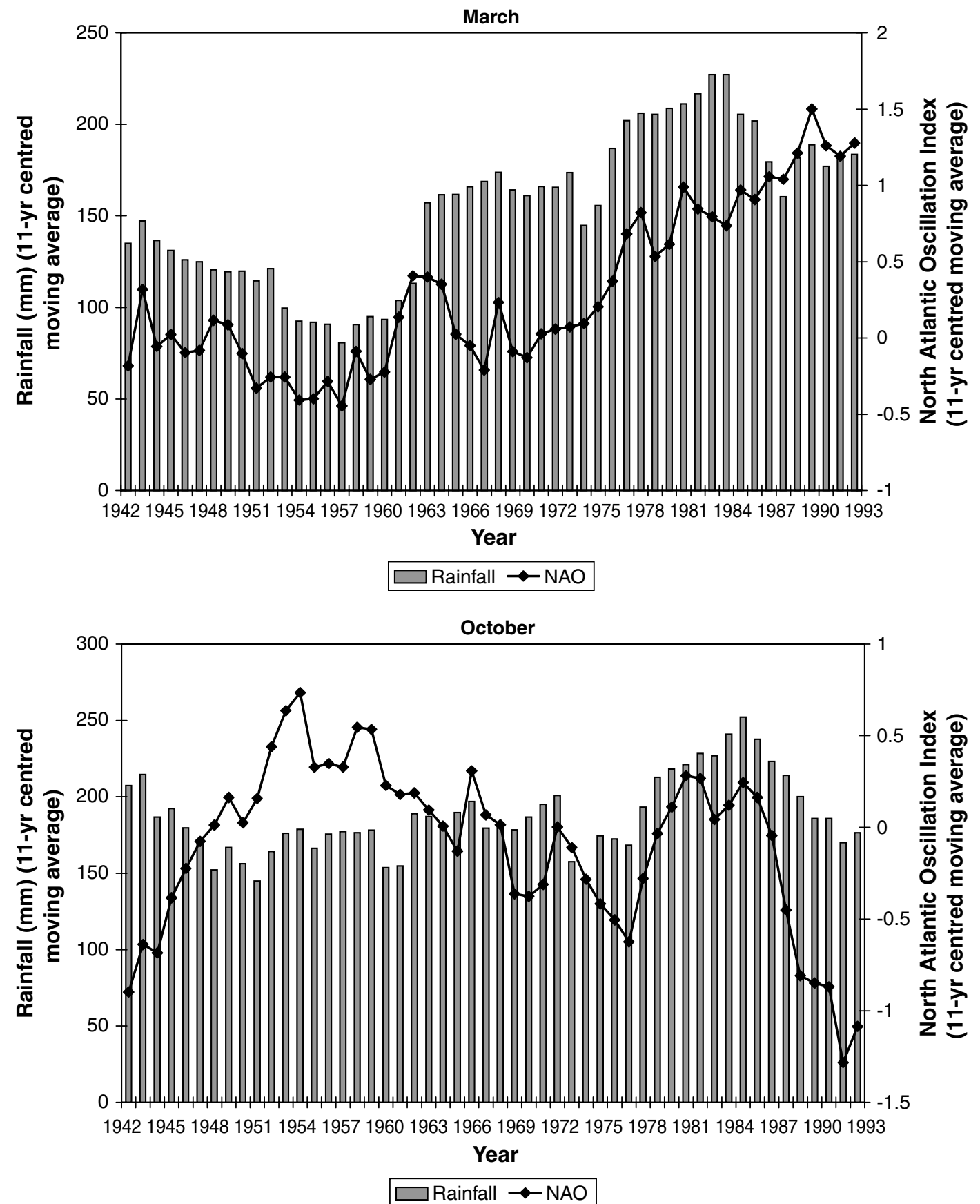

Figure 10. Monthly NAO and precipitation for Moorland Cottage, using data from 1937 to 1998 (11 year centred moving average), for October, November and December

is also related to the NAO. Mean daily precipitation for 'winter' weather states is increased during a high-phase winter-NAO and is, conversely, decreased during a low phase. For summer weather states there is little change. The $24 \mathrm{~h}$ PD is, in general, reduced during a low-phase winter-NAO and increased during a high phase. Variability of summer and winter westerly weather state precipitation is noticeably enhanced during a low phase, 

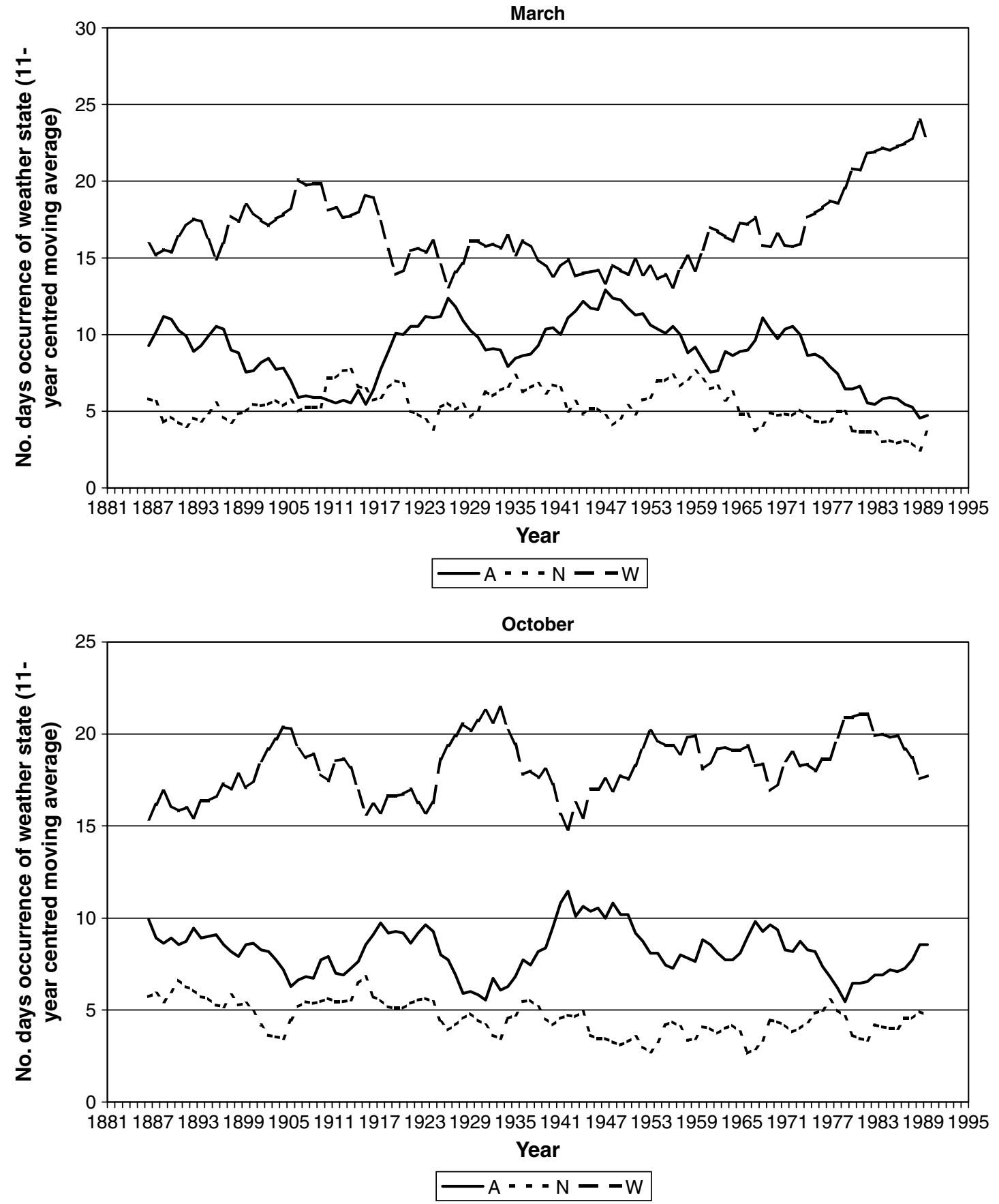

Figure 11. Frequency of occurrence of a weather state in March and October during the period from 1882 to 1998 (11 year mean centred moving average)

but northerly and anticyclonic weather states show reduced variability. These relationships are reversed during a high phase. Precipitation for a particular weather state also varies through time (Figure 13). There has been a reduction in the daily precipitation amount of the westerly weather group in summer since the 1930s. The winter westerlies also show fluctuations that appear to correlate to positive and negative phases of the NAO. 
Table X. Correlation coefficients between monthly precipitation and monthly occurrence of a weather state at the three sites (bold figures indicate a significant correlation at the $95 \%$ level); A, N, W as in Table IX

\begin{tabular}{|c|c|c|c|c|c|c|c|c|c|}
\hline \multirow[t]{2}{*}{ Month } & \multicolumn{3}{|c|}{ Moorland Cottage } & \multicolumn{3}{|c|}{ Lockwood Reservoir } & \multicolumn{3}{|c|}{ Kirk Bramwith } \\
\hline & $\mathrm{A}$ & $\mathrm{N}$ & $\mathrm{W}$ & A & $\mathrm{N}$ & $\mathrm{W}$ & A & $\mathrm{N}$ & $\mathrm{W}$ \\
\hline $\mathrm{J}$ & -0.38 & -0.55 & 0.55 & -0.28 & 0.46 & -0.09 & -0.38 & 0.22 & 0.12 \\
\hline $\mathrm{F}$ & -0.31 & -0.43 & 0.50 & -0.44 & 0.11 & 0.17 & -0.29 & -0.29 & 0.35 \\
\hline M & -0.67 & -0.75 & 0.80 & -0.55 & -0.30 & 0.60 & -0.71 & -0.37 & 0.76 \\
\hline A & -0.14 & -0.27 & 0.36 & -0.61 & 0.68 & -0.05 & -0.60 & 0.59 & 0.02 \\
\hline M & -0.70 & -0.47 & 0.84 & -0.22 & 0.32 & -0.01 & -0.61 & 0.16 & 0.46 \\
\hline $\mathrm{J}$ & 0.03 & -0.26 & 0.29 & -0.15 & 0.07 & 0.05 & -0.18 & 0.33 & -0.18 \\
\hline $\mathrm{J}$ & -0.77 & 0.07 & 0.64 & -0.49 & -0.06 & 0.42 & -0.32 & 0.26 & 0.14 \\
\hline A & -0.47 & 0.17 & 0.42 & -0.50 & -0.02 & 0.41 & -0.56 & -0.19 & 0.53 \\
\hline $\mathrm{S}$ & -0.27 & -0.24 & 0.34 & -0.36 & -0.30 & 0.40 & -0.24 & -0.31 & 0.30 \\
\hline $\mathrm{O}$ & -0.47 & 0.28 & 0.33 & -0.37 & 0.44 & 0.07 & -0.38 & 0.46 & 0.07 \\
\hline $\mathrm{N}$ & -0.46 & -0.13 & 0.47 & -0.21 & 0.48 & -0.07 & -0.33 & 0.50 & 0.03 \\
\hline $\mathrm{D}$ & -0.08 & -0.15 & 0.22 & -0.61 & 0.03 & 0.58 & -0.62 & 0.03 & 0.59 \\
\hline
\end{tabular}

\section{DISCUSSION AND CONCLUSIONS}

Precipitation data from seven long-term daily records around Yorkshire, UK, were examined for evidence of climate change. At all stations, there is evidence of a decline in summer (JJA) precipitation amounts, dropping by $20 \%$ on average since the late 1960s when compared with the 1937-96 average. This is most marked at western sites, which also exhibit a concurrent increase in winter (DJF) precipitation totals since the mid-1970s. This evidence supports the conclusions of Mayes (1996), of recent enhanced seasonality of precipitation. However, unlike evidence from Ireland (Kiely, 1999), there are no significant changes in annual precipitation totals, even at western sites. Since 1975, the increased winter precipitation at western sites has fallen mainly in the month of March. This is consistent with findings from Ireland, but no similar increase was noted in October. March precipitation since 1975 at Moorland Cottage has increased by approximately $30 \%$ when compared with the pre-1975 period. This is exactly half that observed at western coastal sites in Ireland (Kiely, 1999). This also translates to a slight increase in March precipitation at eastern sites in the post-1975 period, with a lowering of both July and February totals.

Variations in precipitation were also linked to both the NAO and groupings of the objective Lamb weather types. Prominent relationships are apparent between large-scale atmospheric circulation and local precipitation. The NAO, the frequency of weather types and precipitation totals are intimately linked on an annual, seasonal and monthly time scale. Strong connections have been found between winter precipitation totals and the winter-NAO, particularly in western Yorkshire where most surface water supplies are located. These may be very important in the future prediction of winter rainfall. If the NAO can be forecast with some skill using SSTs or other variables, then the capability may exist to estimate the winter replenishment of many Pennine reservoirs a few months in advance. It is likely that similar relationships exist in other parts of the western UK, for example western Scotland and northwest England. An extension of this research to include such areas would provide an important predictor of future hydrological drought episodes and allow the forward planning and management of many water resource systems located in climatologically similar regions of the UK.

\section{ACKNOWLEDGEMENTS}

This work was undertaken as part of a Ph.D. thesis funded jointly by the Engineering and Physical Sciences Research Council (EPSRC) and the Environment Agency (Yorkshire and Northumberland Region). 


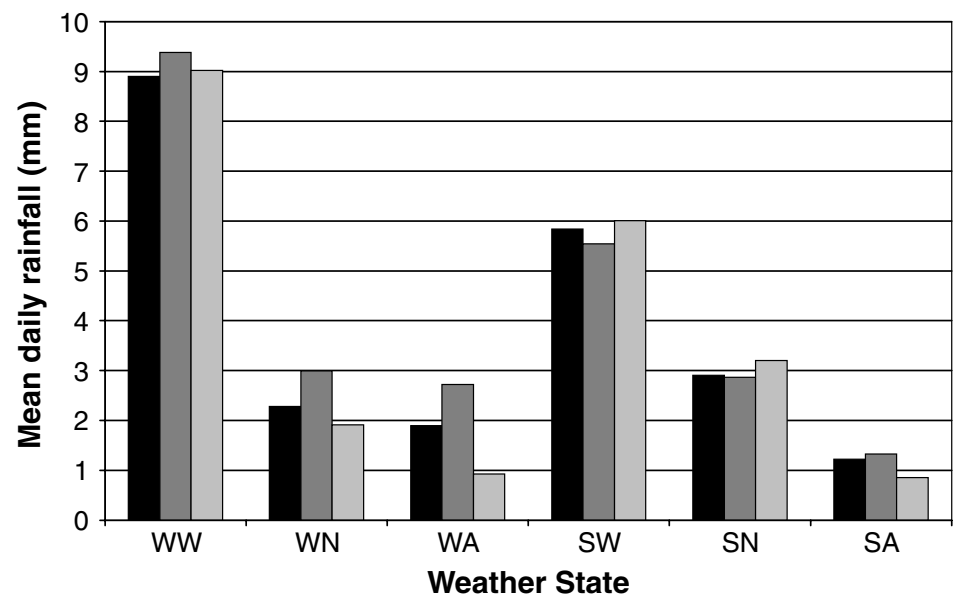

口1961-1990 $\square$ High_NAOI $\square$ Low NAOI

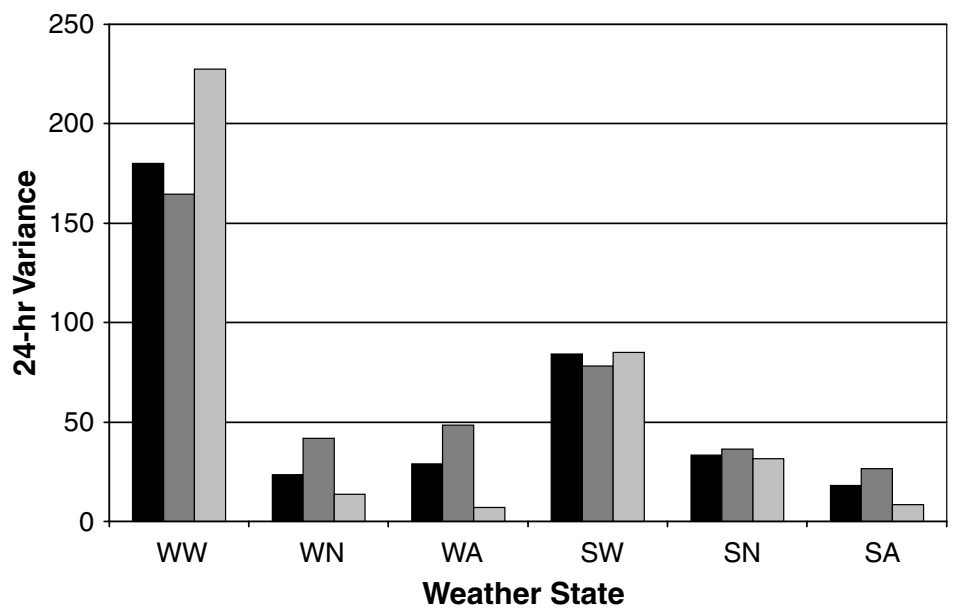

口1961-1990 $\square$ High_NAOI $\square$ Low NAOI

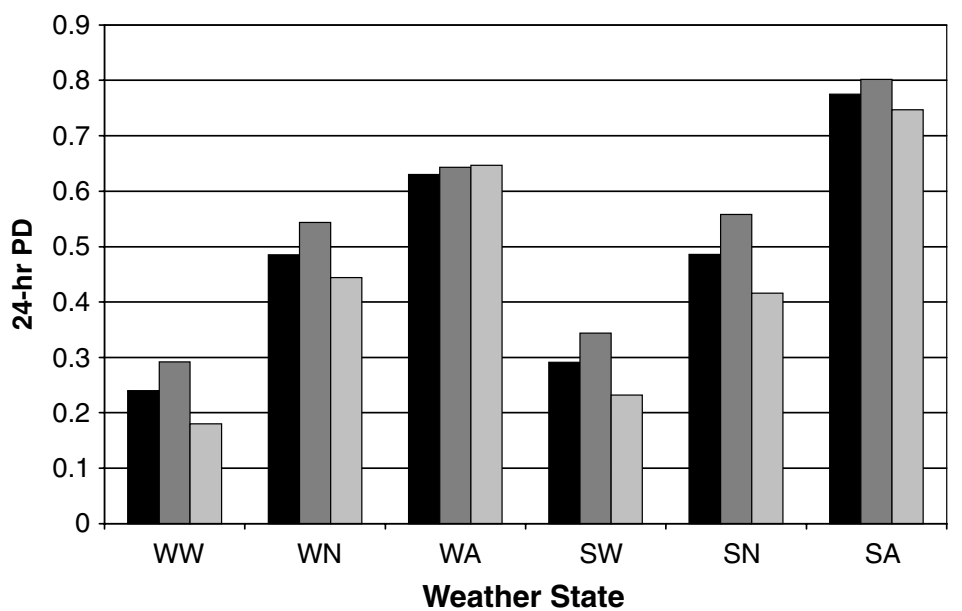

1961-1990 $\square$ High_NAOI $\square$ Low NAOI

Figure 12. Effect of low and high winter-NAO phases upon mean daily rainfall, PD and variance statistics 


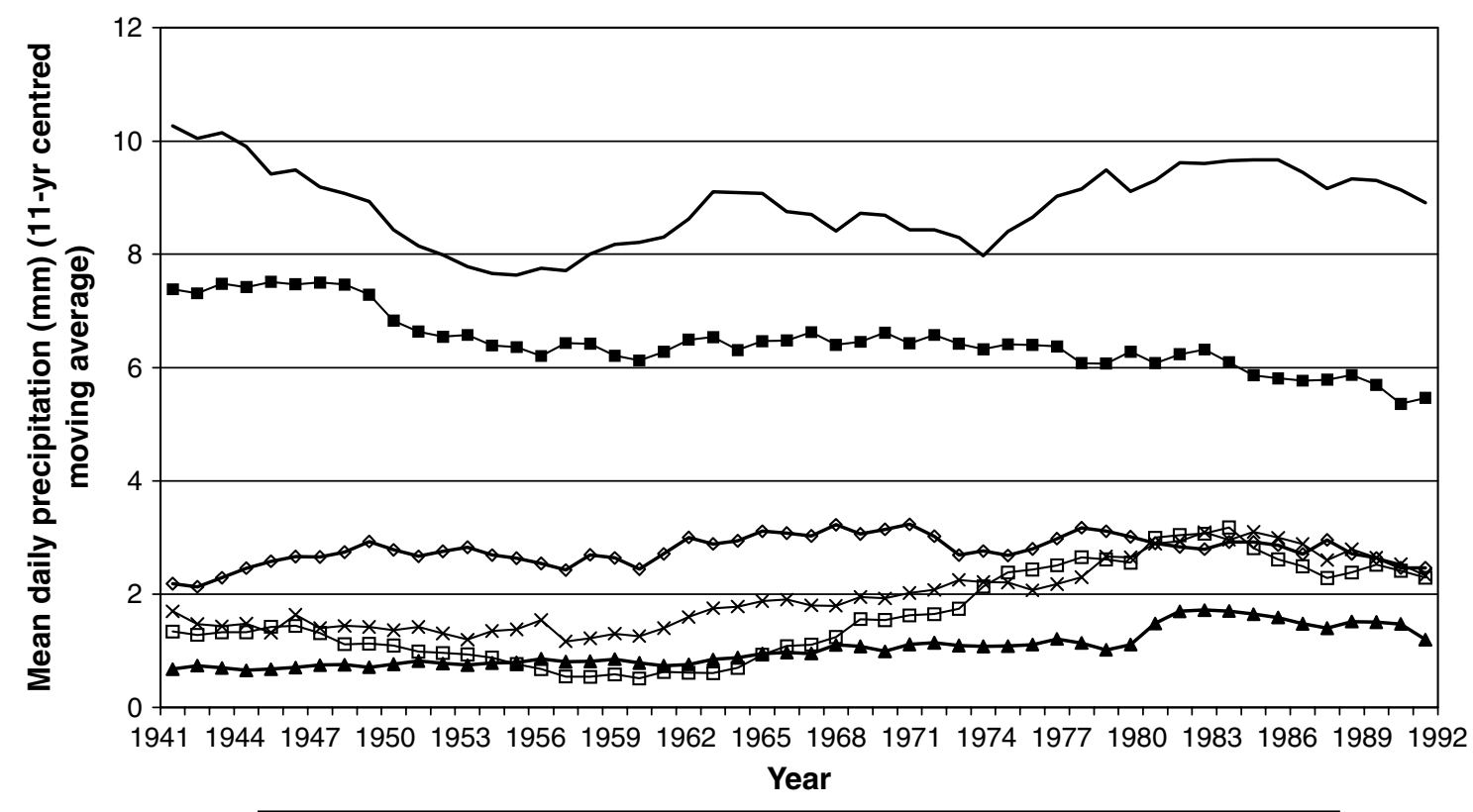

$\leftarrow$ summer-A $\rightarrow$ summer- $\rightarrow$ - summer-W $\square$ winter-A $\rightarrow$ winter- $\mathrm{N} \longrightarrow$ winter-W

Figure 13. Daily precipitation amount at Moorland Cottage associated with the six weather states using data from 1935 to 1998 (11 year centred moving average)

Precipitation data were supplied by Mike Stokes (York EA), and OWT/NAO data by Phil Jones (Climate Research Unit, UEA). Supervision and encouragement from Enda O'Connell are also gratefully acknowledged.

\section{REFERENCES}

Bradley RS, Diaz HF, Eischeid JK, Jones PD, Kelly PM, Goodess CM. 1987. Precipitation fluctuations over Northern Hemisphere land areas since the mid-19th century. Science 237: 171-275.

Brunetti M, Buffoni L, Maugeri M, Nanni T. 2000. Precipitation intensity trends in northern Italy. International Journal of Climatology 20: $1017-1031$.

Burt TP, Adamson JK, Lane AMJ. 1998. Long-term rainfall and streamflow records for north central England: putting the Environmental Change Network site at Moor House, Upper Teesdale, in context. Hydrological Sciences Journal 43: $775-787$.

Delworth TL, Mann ME. 2000. Observed and simulated multidecadal variability in the Northern Hemisphere. Climate Dynamics 16: $661-676$.

Diaz HF, Bradley RS, Eischeid JK. 1989. Precipitation fluctuations over global land areas since the late 1800s. Journal of Geophysical Research 94: 1195-1240.

Easterling DR, Meehl GA, Parmesan C, Changnon SA, Karl TR, Mearns LO. 2000. Climate extremes: observations, modeling, and impacts. Science 289: 2068-2074.

Fowler HJ, Kilsby CG. In press. A weather-type approach to analysing water resource drought in the Yorkshire region from 1881 to 1998. Journal of Hydrology.

Fowler HJ, Kilsby CG, O'Connell PE. 2000. A stochastic rainfall model for the assessment of regional water resource systems under changed climatic conditions. Hydrology and Earth System Sciences 4: 263-282.

Groisman PY, Karl TR, Easterling DR, Knight RW, Jamason PF, Hennessy KJ, Suppiah R, Page CM, Wibig J, Fortuniak K, Razuvaev VN, Douglas A, Forland E, Zhai PM. 1999. Changes in the probability of heavy precipitation: important indicators of climatic change. Climatic Change 42: 243-283.

Hamilton T, Saunders MA. 2000. Seasonal forecasting of the winter NAO using north Atlantic sea surface temperatures. In $A G U$ Chapman Conference on the North Atlantic Oscillation, Galicia, Spain, 28 November-1 December.

Hamilton T, Saunders MA, Rockett P. In press. Statistical prediction of sea surface temperature anomalies in the tropical north Atlantic. Weather and Forecasting.

Hurrell JW. 1995. Decadal trends in the North Atlantic Oscillation: regional temperatures and precipitation. Science 269: 676-679.

Iwashima T, Yamamoto R. 1993. A statistical analysis of the extreme events: long-term trend of heavy daily precipitation. Journal of the Meteorological Society of Japan 71: 637-640.

Jenkinson AF, Collinson BP. 1977. An initial climatology of gales over the North Sea. Synoptic Climatology Branch Memorandum No. 62 , Bracknell Meteorological Office. 
Jones PD, Hulme M, Briffa KR. 1993. A comparison of Lamb circulation types with an objective classification scheme. International Journal of Climatology 13: 655-663.

Jones PD, Jónsson T, Wheeler D. 1997. Extension to the North Atlantic Oscillation using early instrumental pressure observations from Gibraltar and south-west Iceland. International Journal of Climatology 17: 1433-1450.

Karl TR, Knight RW. 1998. Secular trends of precipitation amount, frequency, and intensity in the United States. Bulletin of the American Meteorological Society 79: 231-241.

Kiely G. 1999. Climate change in Ireland from precipitation and streamflow observations. Advances in Water Resources 23: 141-151.

Mayes JC. 1996. Spatial and temporal fluctuations of monthly rainfall in the British Isles and variations in the mid-latitude westerly circulation. International Journal of Climatology 16: 585-596.

McGuffie K, Henderson-Sellers A, Holbrook N, Kothavala Z, Balachova O, Hoekstra J. 1999. Assessing simulations of daily temperature and precipitation variability with global climate models for present and enhanced greenhouse climates. International Journal of Climatology 19: 1-26.

Metcalfe AV. 1994. Statistics in Engineering: a Practical Approach. Chapman and Hall: London.

Murphy JM, Mitchell JFB. 1995. Transient response of the Hadley Centre coupled ocean-atmosphere model to increasing carbondioxide. Part II: spatial and temporal structure of response. Journal of Climate 8: 57-80.

Osborn TJ, Hulme M, Jones PD, Basnett TA. 2000. Observed trends in the daily intensity of United Kingdom precipitation. International Journal of Climatology 20: 347-364.

Rodwell MJ, Rowell DP, Folland CK. 1999. Oceanic forcing of the wintertime North Atlantic Oscillation and European climate. Nature 398: $320-323$.

Rowntree PR, Murphy JM, Mitchell JFB. 1993. Climate change and future rainfall predictions. Journal of the Institute of Water and Environmental Management 7: 464-470.

Stephenson DB, Pavan V, Bojariu R. 2000. Is the North Atlantic Oscillation a random walk? International Journal of Climatology 20: $1-18$.

Sutton RT, Allen MR. 1997. Decadal predictability of North Atlantic sea surface temperature and climate. Nature 388: 563-567.

Sweeney JC, O'Hare GP. 1992. Geographical variations in precipitation yields and circulation types in Britain and Ireland. Transactions of the Institute of British Geographers 17: 448-463.

Wilby RL, O'Hare G, Barnsley N. 1997. The North Atlantic Oscillation and British Isles climate variability, 1865-1996. Weather 52: 266-276.

Zhai PM, Sun AJ, Ren FM, Liu XN, Gao B, Zhang Q. 1999. Chances of climate extremes in China. Climatic Change 42: $203-218$. 